\title{
Assessment of Construction Techniques and Material Usage in İzmir Rural Houses
}

\author{
S. Sarp Tunçoku, Ülkü İnceköse, Tonguç Akış, and Mehmet Ali Yalçın \\ İmir Institute of Technology, Faculty of Architecture, Izmir, Turkey
}

The domestic architecture in the rural villages of Izmir comprises a unique built environment with their masonry wall textures, semi-open sofas, round tiled-hipped roofs, and chimneys, and represents an important part of the cultural and architectural heritage. This assessment is mainly based on field observations that focus on the architectural and structural layout of intact, damaged, and destroyed houses. During field observation and the analysis of data certain plan typologies and relationships between the geological formations of the region and choice of materials and construction techniques were observed. While load-bearing masonry and timber skeleton systems are common, extensive use of timber laces, stone, and fired or adobe brick masonry with mud mortar and timber frames infilled with masonry materials were frequently seen. Generally, round timber elements such as wall plates, laces, lintels, posts, and frames of flooring systems are used. Architectural degenerations in authentic houses, defective details and partially due to the earthquake-prone nature of the region seismicity have been evaluated. An overall approach for the preservation and sustainability of this heritage is suggested.

Keywords İzmir rural houses, masonry, infill frame, adobe, mud mortar, seismicity

\section{INTRODUCTION}

Vernacular houses have long been the subject of research carried out in different parts of the world with different approaches to the built environment in rural areas. While some studies focus on the determination of dwelling and settlement types in specific regions (Dickinson 1949; Enayat 1952), others are based on social aspects such as cultural transformation due to the changes in domestic life (Hanan 2012), such as the education of younger generations to raise awareness of drastic changes in rural areas (Baine et al. 2000). The studies on aesthetic qualities and design approaches for farmhouses and rural landscapes (Saleh 2001; Torregiani and Tassinari 2012; Fuentes 2010) are followed by those concentrated on the

Received October 29, 2013; accepted March 8, 2014.

Address correspondence to S. Sarp Tunçoku, İzmir Institute of Technology, Faculty of Architecture, 35430 Gülbahçe, Urla, Izmir, Turkey. E-mail: sarptuncoku@iyte.edu.tr

Color versions of one or more of the figures in the article can be found online at www.tandfonline.com/uarc.

environmental performance of rural settlements regarding their sustainability (Visilia 2009; Cardinale, Rospi, and Stefanizzi 2013; Okinomou and Boigiatioti 2011). In addition to studies at the social and environmental level, others concentrate on the properties of construction materials, particularly adobe (Ngowi 1997; Goodhew and Griffiths 2005; Delgado and Guerrero 2006; Quagliarini and Lenci 2010; Pachego-Torgal and Jalali 2012; Silveira et al. 2012; Adorni, Coïsson, and Ferretti 2013) and analytical/experimental studies on specific construction techniques (Murakami 2000; Hughes 2000a; Makarios and Demosthenous 2006; Chen 2012) in terms of seismic performance (as partially referred in this study) for their salvation. The necessity of preservation and sustainability of such a heritage is commonly emphasized in these studies.

In Turkey, despite many studies about traditional Anatolian houses in towns and cities (Eldem 1955; Aksoy 1962; Kuban 1995; Günay 1998; Küçükerman 2007), studies on construction techniques, particularly employed in rural houses are rather scarce (Kafesçioğlu 1949; 1955; Özgüner 1970; Eriç 1979; Batur 2005). In the past decades when earthquakes resulted in the collapse of numerous new buildings and a high death toll, national and international attention was directed to the seismic performance of traditional dwellings located in the same disaster areas that survived (Hughes 2000b; Tobriner 2000; Gülkan and Langenbach 2004; Doğangün, Tuluk Livaoğlu, and Acar 2006; Şahin-Güçhan 2007; Langenbach 2007).

Historical houses that survived in Turkish towns and cities rapidly lose their original features due to major alterations and interventions that utilize inadequate materials and techniques while their original built-environments are also changed through new development plans. On the contrary, a remarkable portion of rural houses built by local master builders are still intact and reflect the achievement of well-organized guilds of masons, carpenters, ironsmiths, brickmakers, and plasterers who were trained by a mentorship-tradition in centuries. As belonging to the beginning of the 20th century and early decades of the republican period, İzmir's rural houses can be considered as the latest productions of a deeply rooted building practice which continued until the 1960s when Turkey started to transform its agricultural economy to that of an industrial one. Consequent changes in lifestyles and building traditions 
followed largely due to mass migration into the cities especially after the 1970s when the young population drastically declined in search of jobs and opportunities of education in cities. Rural areas were impoverished with a highly aged population, causing the total disappearance of guilds and lack of maintenance and abandonment of many houses.

Fortunately, public institutions have recently involved in preparing inventories of rural settlements that cover larger areas in different regions, which are not only concerned with architectural characteristics but also their cultural, social and economic aspects. ${ }^{1}$ This study is based on partial results of field research with the main objective to produce an inventory 416 villages, which remain outside the municipal boundaries of the Greater Izmir Metropolitan Municipality. The research was funded by the Special Provincial Administration of İzmir Governorship as a continuation of the previous public efforts and carried out by a group of scholars of the Faculty of Architecture at İmir Institute of Technology. ${ }^{2}$ This study particularly focuses on construction techniques and materials employed in rural houses from 27 villages, which were found to be representative of geographical, architectural and social structure of the villages around Bergama, Kınık, Aliağa, and Dikili in the north; Urla, Çeşme, and Karaburun in the west, Bayındır, Ödemiş, Tire, Beydağ, and Kiraz in the east, and of Selçuk in the south) which they are administratively connected (Figure 1). ${ }^{3}$

\footnotetext{
${ }^{1}$ The works about rural settlements of Kayseri and Balıkesir cities were sponsored by the Ministry of Public Works and Settlements General Directorate of Technical Research and Application. Both works were carried out by a team coordinated by Prof. Dr. Kemal Çorapçığlu from Mimar Sinan Fine Arts University, Faculty of Architecture (Çorapçığlu et al. 2008, 2011).

${ }^{2}$ The work, coordinated by Prof. Dr. Murat Günaydın from the Faculty of Architecture of İzmir Institute of Technology, was initiated in 2010 and composed of three parts. The first part was a thorough survey of 416 villages for the determination of the overall characteristics of their geographical, social, and built environments. The second part included detailed interviews with the families to determine the problems and requirements, observations for architectural characteristics of each settlement, architectural measurements of at least two representative houses in terms of architectural layout and construction techniques-including 65 houses in total, and the rough-scaled sketches of authentic, altered and newly built houses carried out for 27 villages representing the rural characteristics of the districts. Basing on these two inventory parts, the final aim of the work, being the third part, was the provision of the complete sets of cost-free projects for the houses (including architectural, structural, mechanical, and electrical application projects) of different size and programs as an aid for the villagers having limited finance. The complete report titled, The Inventory of the Settlements and Houses of Izmir Rural and Provision of Exemplary House Projects, was prepared for publication by S. S. Tunçoku, A. Avar, Ü. İnceköse, T. Akış, and M. A. Yalçın and was published in the Turkish language by the Special Provincial Administration of İzmir Governorship in May 2012 (Tunçoku et al. 2012).

${ }^{3}$ The names of the villages are given following the name of the district. Unless stated with the related reference, all figures were produced during the work and placed in the report.
}

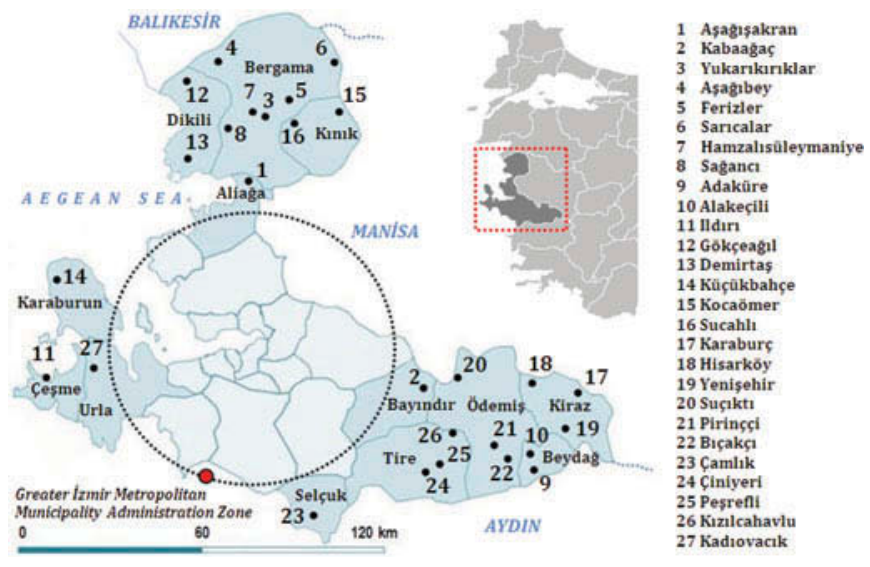

FIG. 1. Districts of İzmir and the villages representing their rural characteristics.

Following brief information about the historical background and the geographical characteristics of İzmir, an evaluation of the general features of Anatolian houses will be given regarding the relationship of the social structure to the plan layout, and the geographical conditions that affect the construction techniques and the materials used. In addition to the houses that survived with their authentic features, altered, damaged and collapsed houses are also considered in the overall evaluation in terms of their preservation and sustainability. Here it should be noted that this study is an assessment of the constructional features of a vast built environment of Izmir rural, and that the cases, which may not be matched well with the most representative ones, tried to be presented in this article are certainly available.

\section{HISTORICAL BACKGROUND AND GEOGRAPHICAL CHARACTERISTICS OF IZMIR}

Being one of the oldest cities in the Mediterranean basin, as a human settlement İzmir (known as Smyrna) dates to prehistoric ages, according to recent excavations. In a brief chronological order, the city was ruled by Trojans, Aeolians, Lydians, Persians, Romans and Byzantines, Seljuks, and the Sons of Aydin Bey during the Principalities Period, and by the Ottomans. İzmir is still an important port city for trade and cultural tourism since the establishment of the Republic of Turkey in 1923.

With the Çeşme and Karaburun promontories, it is the second main extension of the Anatolian peninsula towards the Aegean Sea following the westernmost Bababurun promontory to its north. Neighboring cities are Balıkesir to the north, Manisa to the east and Aydin to the south. Together with its districts on which İzmir is situated; Büyük Menderes, Küçük Menderes, Gediz, and Bakırçay grabens are named according to the rivers that run through the alluvial plains between Bozdağ and Aydın mountain ranges on the east-west direction and the Yamanlar, Yunt and Madra mountains towards the north. Their altitudes 


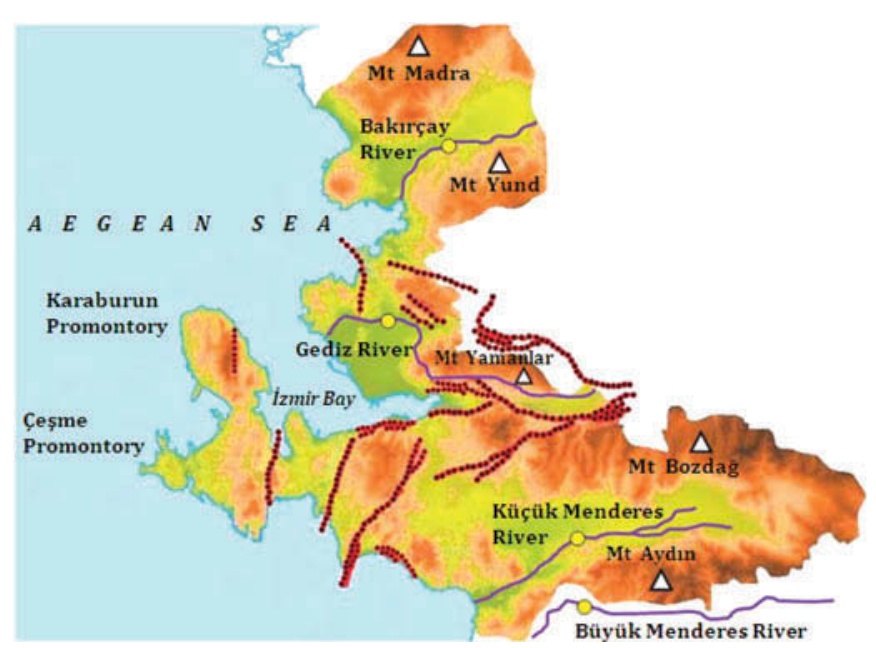

FIG. 2. Topography and active fault lines of İzmir. @ Ertan Kara. Reproduced by permission of Ertan Kara. Permission to reuse must be obtained from the rightsholder

vary from 1350 to $2160 \mathrm{~m}$. Active faults on the north-south and east-west directions makes İzmir a first-degree earthquake zone like the rest of the Aegean Region (Figure 2).

Geological structure of Izmir is determined by the Menderes Massif in the south, the İzmir-Ankara Suture in the north, and the Bornova Flysch Zone in between (Maden Tetkik ve Arama Genel Müdürlüğü [MTA] 2005; Okay 2008). Such a diversified geological formation of magmatic, sedimentary and metamorphic rocks is reflected in the stone masonry construction of the area. Owing to the rich forest sources in the past, various kinds of wood such as yellow and red pine, chestnut and oak were mostly preferred for the timber components of houses.

\section{CHARACTERISTICS OF IZMIR RURAL HOUSES}

In addition to the habits of Turkish nomadic way of life environmental conditions such as climate, topography, raw material sources, Islamic way of life and the influences of preexisting cultures have shaped housing layouts of new settlers in towns and rural areas in Anatolia. The sociocultural and socioeconomic structures of any society have an important role in the development of civil architecture. However, contrary to many other societies, in Ottoman society mobility in different social classes was relatively flexible. Therefore, the spatial layout remained constant in the majority of houses built not only in towns, but also in villages. In other words, plan layout of the houses of ordinary people is not very different from those of the rich. The main difference remains in stylistic features that are more elaborate, or the size of spaces, which are larger in the houses of the nobles or the rich (Kazmaoğlu and Tanyeli 1979).

Briefly, the level where daily life mainly takes place in an Anatolian house is composed of a central space called sofa and the rooms around it. The ground floor is generally assigned to service units, such as stables, storage, and kitchens. When the parcel of the house has an irregular geometry, the upper floors in multi-story houses is adjusted to have a regular geometry by projections such as overhanging bays or jetties. This arrangement is frequently observed in urban houses where parcel geometries vary considerably.

Except for the toilet, which is usually located outside the house, each room should provide optimum conditions such as suitable orientation and equipment for sleeping, sitting, and even dining where all cupboards and closets that are arranged on the blind or the so-called service wall (Asatekin 2005) in the rooms. One of the closets contains a bathtub for the performance of ablution and is called gusülhane. Ablution is performed with carried-water, and wastewater is drained out through simple stone, zinc, or wooden spouts, and rarely through lead pipes. Such private uses of each room in a single house are attributed to the individual nomad tents of the same family (Günay 1988; Kuban 1995; Köse 2005).

Some rooms may be frequently used according to the seasons, such as rooms for summer or winter use. The sofa, also called hayat, hanay, sergâh, ayazlık, çardak, and divanhane in different regions, is the production center of the daily life of self-sufficient family who lived in towns or in rural areas.

The classification of the plan layouts is done according to the location of sofas, such as houses with inner (or central or closed) sofas or those with outer (or open) sofas (Eldem 1955; Kuban 1995). The number and distribution of rooms around the sofa may vary depending on each type. Excluding the depth of closets (including ablution tub gusülhane) the rooms are square or rectangular close to square. Their sizes vary from 12 to $22 \mathrm{~m}^{2}$.

In addition to the existence of single-story houses where the main floor is the ground floor, the major group in İzmir's rural areas is made up of double-story houses with outer sofas. Contrary to the incongruence between the ground and main floor plans of the houses in urban areas, the plan geometry of the ground and main floors of rural houses of Izmir is relatively constant and usually rectangular. While the word sofa is generally used as the term of reference, hayat refers to the sofa of the single-story houses, hanay to the sofas at the second floor, and mağazalık to the storage spaces in the ground floors of multistory houses among the villagers. Especially in the hot summer, the sofa is breezy and therefore the most enjoyable space in the house. While the depths of the sofas vary from $2.5 \mathrm{~m}$ to $4 \mathrm{~m}$, their lengths are determined by the number and total width of the rooms covering an approximate range of 7 to $11 \mathrm{~m}$. The widths of inner sofas do not exceed $2.5 \mathrm{~m}$. Similar to those with outer sofas, their lengths are determined by the total width of the rooms on both sides.

In addition to available material sources in the area, another important determinant is the village topography that affects the plan layout, the connection between the ground and upper floors, and the entrance to the houses. Therefore, the rural houses of İzmir can be classified as those located by the seaside, on plains, and on higher lands. 


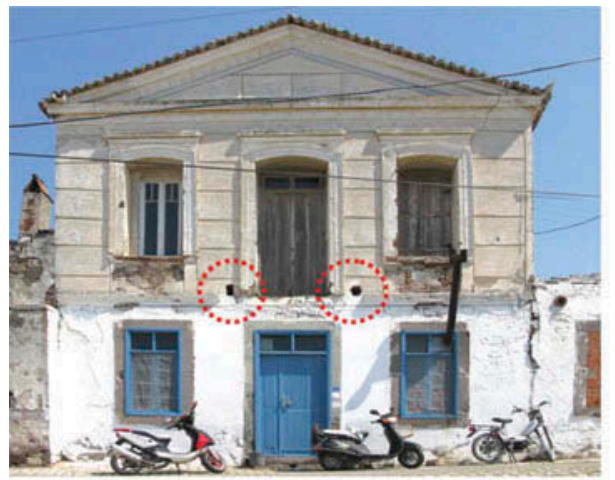

(a)

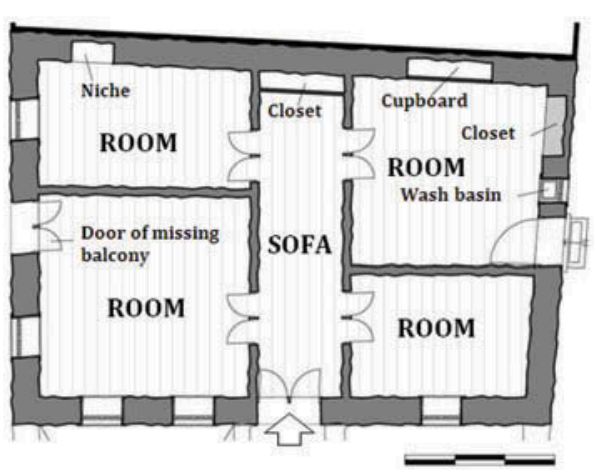

(b)

FIG. 3. A double-story house with inner sofa (Çeşme-Ildırı): (a) Main facade and the traces of missing balcony, and (b) first floor plan.

As well as fishing and/or agriculture, the villages by the seaside always had commercial importance and the houses there accommodated the families of the merchant class, usually of non-Muslim descent. Not strictly limited to coastal zones, these houses are generally double-story with inner sofas and built partially of ashlar, roughly cut rubble stone with irregular courses of fired brick, or partially fired brick resting on the stone masonry walls of ground floors. Their construction techniques, facade layouts, and details resemble the neo-classical Levantine houses of Izmir, many of which were built by Greek craftsmen in the late Ottoman Period (Erpi 1975; 1987), as shown in Figure 3a-b).

The houses of the villages on plains are usually single-story buildings with courtyards, and they form the major group in these settlements (Figure 4a-b). Entered through a double-wing door with a canopy above courtyards are usually enclosed with masonry walls of $2-2.5 \mathrm{~m}$ height and $40-50 \mathrm{~cm}$ thickness and possess service units such as furnace, toilet, barns, and storage spaces. However, double-story houses with or without courtyards were also observed (Figure $4 \mathrm{c}-\mathrm{d}$ ). In addition to stone, another widely used material is adobe brick. In even greater number than those in the villages at the seaside and higher lands, double-story houses built of fired bricks are also seen on the plains.

Depending on the ratio of the slope and access from the street or garden, architectural layout of the houses of villages at high lands varies. The entrance to the main floor is generally provided through the sofa. It is accessed by the stairs from the ground floor raised by 2 to 5 steps from the garden, which corresponds to the lower level of the slope. The garden, and rarely the courtyard, is reached by stairs descending from the street. It is also observed that the main floor-sofas of some houses are accessed directly from the street. The sofas in these floors are connected to the garden below by stairs. Except for the houses with inner sofas and those entered directly from the upper level of the slopes by assigning one side of the sofa, the majority of houses in the rural areas of İzmir on sloped lands are accessed through the gardens below. They are mainly built of stone, but adobe brick is also used as construction material in the houses on high lands.

\section{STRUCTURAL LAYOUT, AND MATERIAL USE}

Regardless of the number of stories-in fact, not more than two stories in general - the rural houses of Izzmir are composed of U-shaped masonry, generally of stone at least until the level of the first floor with minimum openings, which envelop the interior structure that includes partition walls and timber floors. The height of floors varies from 2.3 to $2.6 \mathrm{~m}$. The semi-open side, usually facing south is allocated to the front walls of rooms accessed through the sofa on the first floor, while the front walls of the stables and storage spaces at the ground floor are accessed below the sofa.

Regarding their load-bearing systems, İzmir's rural houses can be defined as composite structures because of the combined use of masonry (stone and fired or adobe brick) and timber frame infilled with brick, earth or stone fragments with mortar. The infilled frame system is called hımıs and differs from the sole use of timber seen especially at the waterside residences (called yall) of the Marmara Region where the exterior face of timber frame is clad with weatherboards, nailed to the frame, slightly lapped onto the one below, and never plastered. In this system, the interior faces of walls are covered with plaster applied on wood laths, which is called the bağdadi plastering technique.

Although not seen during the field observation, but known from the footings of other houses in Aegean Region, the footings placed in varying depths are of rough-cut rubble stones that protrude $10-15 \mathrm{~cm}$ from both faces of the walls that rest on them (Irgat Ergin 2007). Up to the ground floor level, such a substructure was a common building practice for traditional houses either built of stone and fired or adobe brick in Anatolia.

In some houses, it is also observed that some walls rest directly on bedrock outcrops of kayrak, ${ }^{4}$ granite and andesite

\footnotetext{
${ }^{4}$ Usually used as a pavement material, kayrak, which corresponds to a metamorphic rock type—slate (ardoise in French)—is synonymously
} 


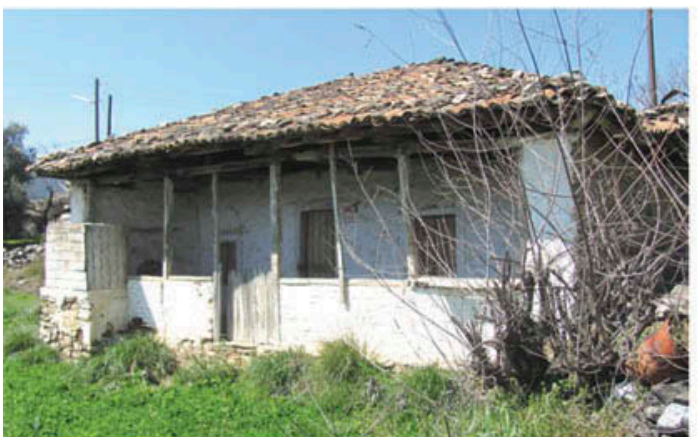

(a)

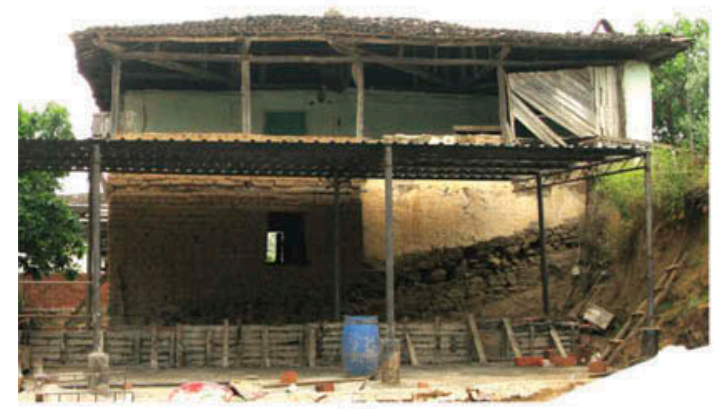

(c)

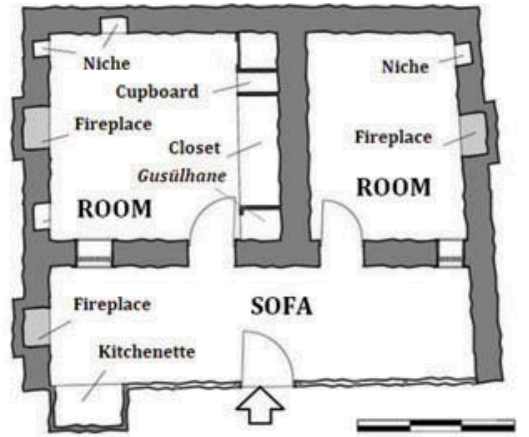

(b)

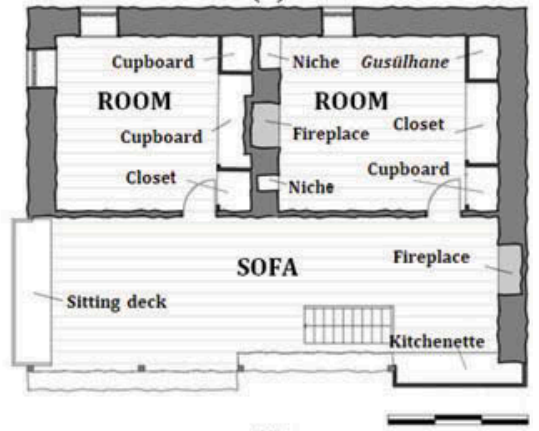

(d)

FIG. 4. (a-b) A single-story house with outer sofa (Kiraz-Hisarköy); (c-d) a double-story house with outer sofa and a latter addition of a semi-open barn (Kiraz-Yenişehir).

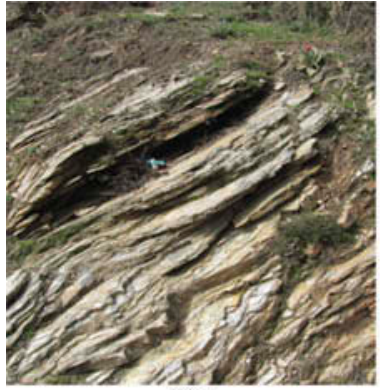

(a)

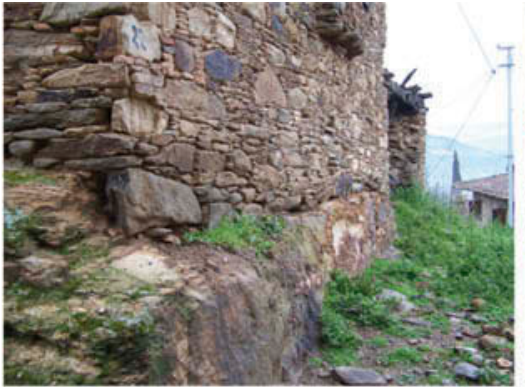

(b)

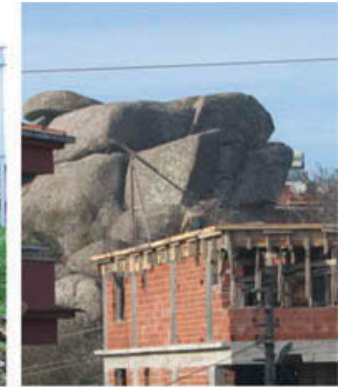

(c)

FIG. 5. (a) Deposits of foliated rock (Ödemiş-Kerpiçlik); (b) a house directly rest on bedrock (Beydağ-Alakeçili); (c) granite outcrops (Bergama-Kıranlı).

deposits immediately below, eliminating the need for foundation trenches (Figure 5).

In addition to their structural properties, walls are described together with their inclusions such as fireplaces, chimneys, openings in which doors and windows are placed, and timber laces, called hatıl embedded in masonry. Similarly, floors are described together with their extensions such as; bay windows/jetties (called jumba), and stairs providing vertical circulation between floors, and roof constructions with eaves.

used as kayăgan and arduvaz by stone sellers in Turkey. However, the term kayrak is customarily used by the locals not only implying slate but also stone slabs easily obtained from foliated rocks in varying colors from grayish-green to dark blue or dark or pale yellow to light brown without considering its mineralogical composition.

\subsection{Walling Systems}

\subsubsection{Stone masonry walls}

Relating to local geology, masonry walls of rural houses and their annexes are composed of rough-cut rubble bonds of kayrak (of metamorphic group), granite and andesite (of magmatic group), and different kinds of limestone (of sedimentary group). Although not frequently observed, stones collected from fields and riverbeds, which are not necessarily suitable for masonry construction, were also used in the masonry walls of some houses (Figure 6).

Generally, the use of cut stone is limited to the quoins of the houses. It may not be necessarily of ashlar, but the use of relatively better-shaped and/or larger sized stones in the corners of masonry structures is common in the region. Although rarely observed, some houses as those in coastal villages and the 


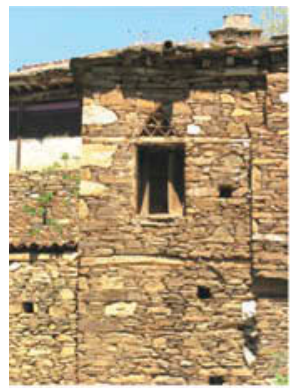

(a)

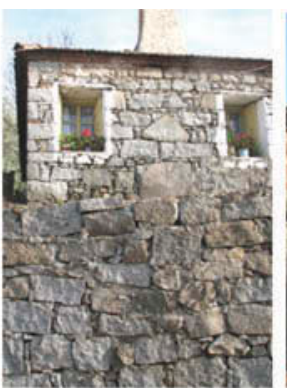

(b)

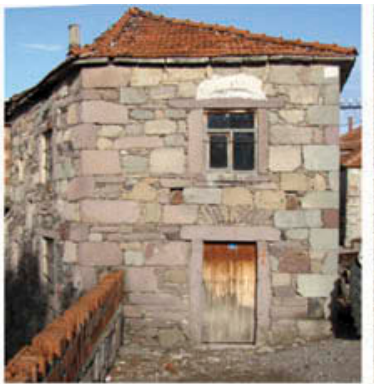

(c)

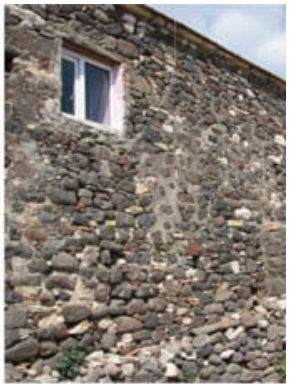

(d)

FIG. 6. Stone masonry houses built of: (a) kayrak (Bayındır-Kabaağaç), (b) granite (Bergama-Kıranlı), (c) andesite (Kınık-Örtülü), and (d) field rubble (UrlaKadıovacık).

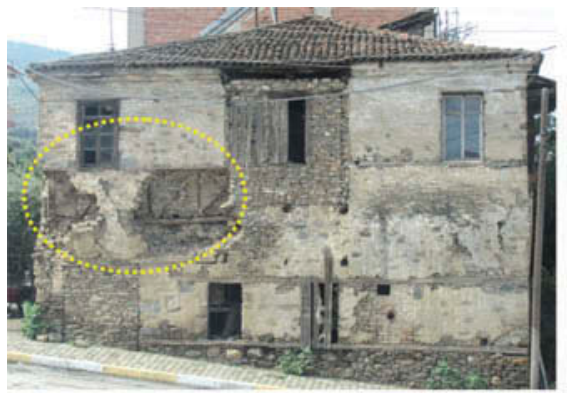

(a)

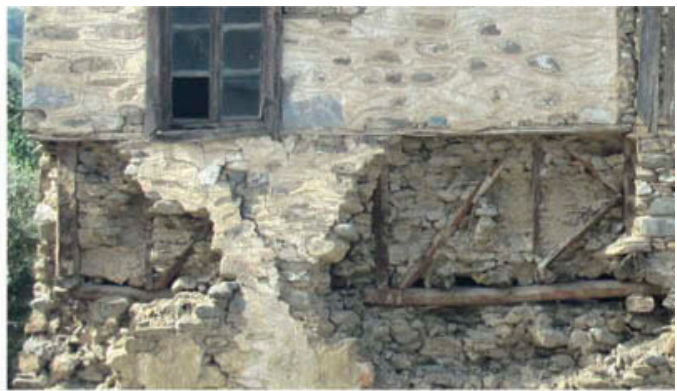

(b)

FIG. 7. (a) A damaged house built of double-leaf masonry; (b) close-up view of the outer stone masonry leaf and hımış inner frame (Kiraz-Yenişehir).

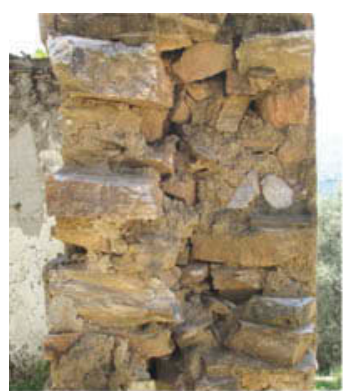

(a)

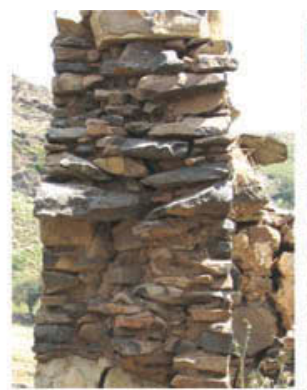

(b)

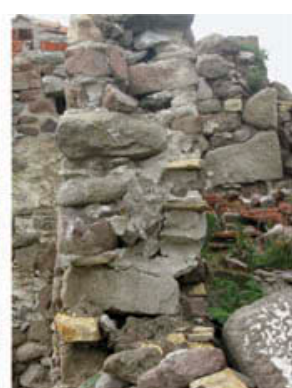

(c)

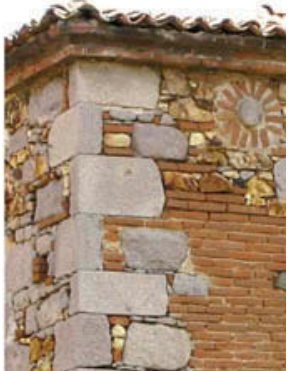

(d)

FIG. 8. (a) A wall with double-leaf (Bayındır-Kabaağaç); use of through stones (b) Karaburun-Küçükbahçe; (c) Bergama-Yukarıkırıklar; (d) use of stone and brick (Bergama-Sağanc1).

villages of commercial importance, are completely or partially of cut stone, most likely belonging to the well-off families in the past.

Ground floor walls of multistory houses are built of stone with minimum fenestration. The material of the walls above ground floors may vary, such as fired or adobe brick or infill frame, termed hımış. However, in many examples, stone masonry also extends till the level of the eaves. Sometimes interior part of this U-shaped masonry may include a second leaf in its interior at the upper floors, which is also built of hımıss (Figure 7).

Regardless of stone type, the thickness of load bearing stone masonry walls varies from 50 to $60 \mathrm{~cm}$. Although not as conspicuous as the infilled part between the inner and outer leafs of the building walls of monumental scale, one may still differentiate the outer and inner leafs of the masonry walls in this region, and therefore they may not be defined as solid walls (Figure 8a). It was possible to observe through stones interlacing with the opposite leaf in the wall bonds of some collapsed houses (Figure 8b-c). In addition to stone, bonds of brick with stone are also observed in the masonry parts of many Izmir rural houses (Figure 8d).

Within these variations, the most widely employed stone in the region is kayrak. Being a foliated metamorphic rock, kayrak blocks can easily be separated into slabs of desired size which gives way to a speedy construction on the contrary of andesite and granite rocks that need cutting and carving. 


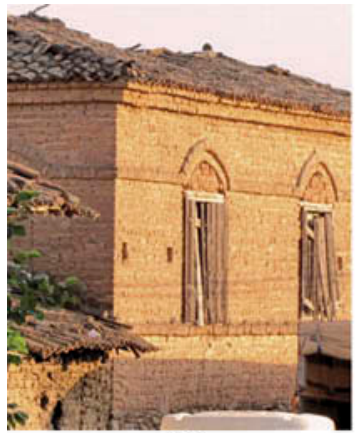

(a)

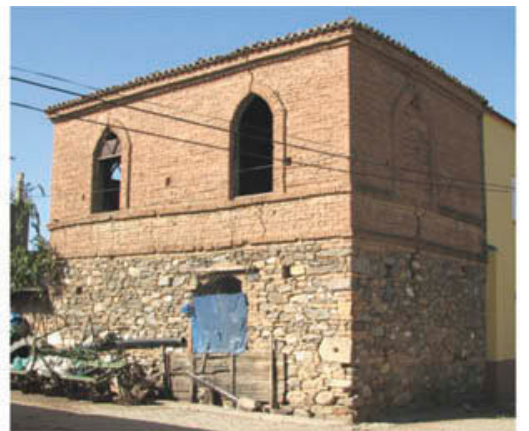

(b)

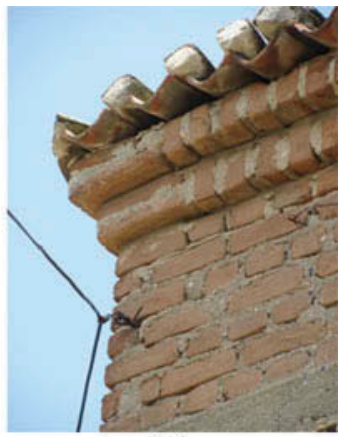

(c)

FIG. 9. Brick masonry houses with fired brick moldings and eaves: (a) Ödemiş-Yolüstü, (b) Tire-Kızılcahavlu, and (c) (Tire-Kızılcahavlu).

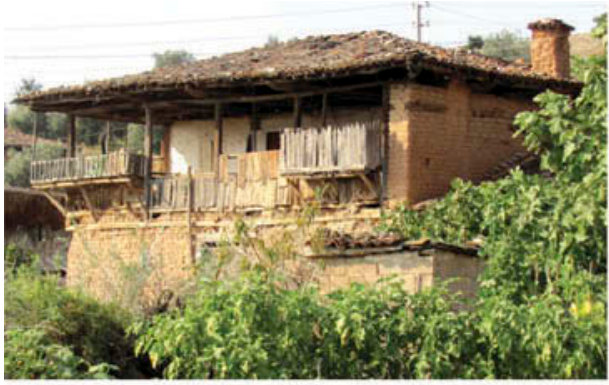

(a)

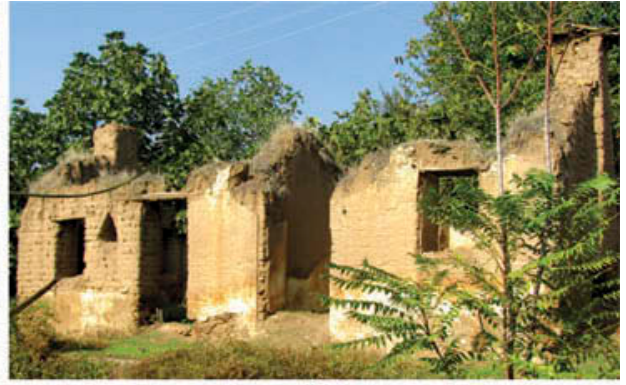

(b)

FIG. 10. (a) A double-story adobe brick masonry house; (b) remains of an adobe brick masonry house (Ödemiş-Alaşarlı).

\subsubsection{Brick masonry walls}

As they are preferred in the villages on plains, rarely built brick masonry walls of houses rest on the stone masonry walls of ground floors. Locally produced pressed-bricks of 9/19/5-6 cm and bricks from the nearby Greek islands, especially from Chios (Erpi 1987) very close to the Çeşme promontory of Izmir, were also used. Eaves that are composed of rows of bricks in plain or saw-tooth-order, brick casings, flat or curved arches with varying profiles around doors and windows and houses that possess brick moldings at the levels of floors and windowsills were also observed (Figure 9).

The exterior faces of masonry walls made of either brick or stone are rarely plastered. Such a preference resulted in the wall textures identical to the rural houses in the region.

\subsubsection{Earth walling}

Especially in the villages located on plains, adobe brick is the most widely used masonry material in the region. It is the mixture of mud, sands of varying grain size, chopped straw and sometimes small amount of lime as stabilizer and animal dung as an adhesive and plasticizer, which are regarded 'ecofriendly' additives (Ngowi 1997; Yetgin, Çavdar, and Çavdar 2008; Quagliarini and Lenci 2010; Pachego-Torgal and Jalali 2012; Adorni, Coïsson, and Ferretti 2013). They are molded in wooden formwork and exposed to the sun to dry. It is also used as infill material in the compartments of hımış frames of the walls defined below. Their colors vary from pale yellow to dark red or brown depending on the mineral composition of clay. Although usually used for animal barns and other annexes, many elaborate adobe brick masonry houses built of stone or brick masonry with similar plan layouts are also observed (Figure 10a). The walls made of adobe (either masonry or infillframe with adobe) are plastered and whitewashed since they are vulnerable to water. Due to the lack of periodical maintenance, such vulnerability caused the walls of plenty of houses to be damaged or totally collapsed (Figure 10b). Adobe production still continues in some villages.

Ornaments specifically composed of brick and/or stone embedded in masonry, which do not have a structural purpose, are frequently seen on facades. Probably such ornaments are the logos of the masons who constructed the house (Figure 11a-b). In addition to such ornamentation, the skulls of rams or bulls (sacrificed at the beginning of the construction as a rite) with horns, believed to be protective against evil eye or wish for fertility and good luck are also embedded in the facades visible from outside (Figure 11c-d).

\subsubsection{Timber laces in masonry walls}

As pointed out at the beginning, the region is in a firstdegree earthquake zone in Anatolia. Regardless of the kind of masonry used, timber laces (called hatıl) play important roles in buildings from the point of view of structural-stability 


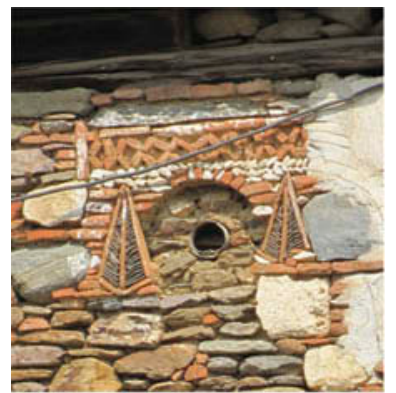

(a)

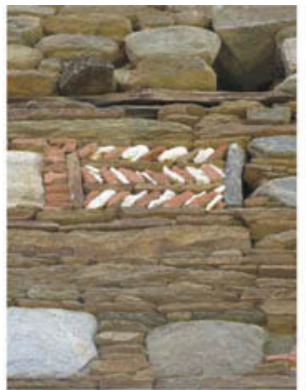

(b)

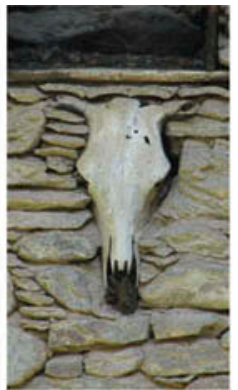

(c)

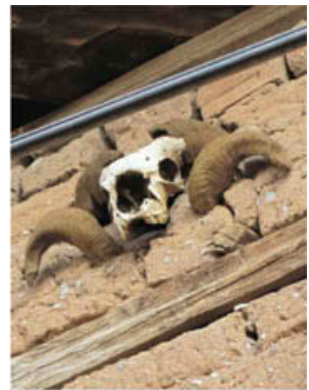

(d)

FIG. 11. Logos of masons: (a) Tire-Peşrefli, (b) Tire-Çiniyeri and amulets, (c) Beydă̆-Çomaklar, and (d) Ödemiş-Alaşarlı.

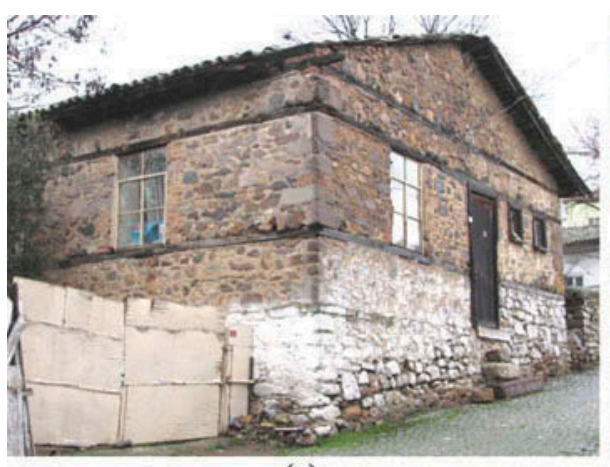

(a)

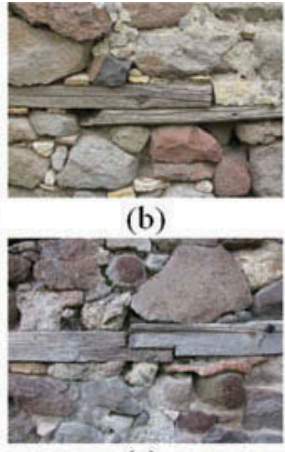

(c)

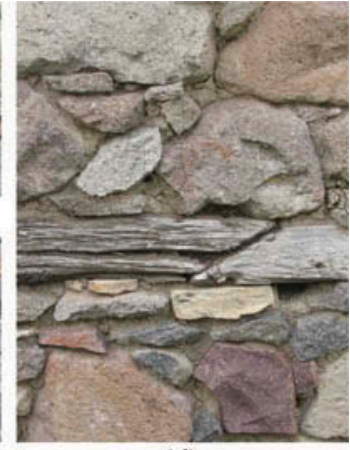

(d)

FIG. 12. (a) Thorough use of hatıl (Bergama-Sağancı) and joint types of hatıls (Bergama-Yukarıkırıklar): (b) butt joint, (c) half-lapped joint, and (d) diagonal cut.

against earthquakes (Tobriner 2000; Hughes 2000a; 2000b; Langenbach 2007). Depending on the bonding technique and the thickness of the wall, they are embedded either into the outer and inner faces of the wall, or aligned side-by-side adjusted to the width of the wall when used as lintels for door or window openings. They are also found at the levels of windowsills, lintels, and eaves (Figure 12a). Some examples demonstrate a continuous lacing around the perimeter of the building, but the intermittent use of laces is more common in the region.

While utilized for leveling masonry bonds at certain vertical intervals, usually of $1-1.5 \mathrm{~m}$, the laces distribute the loads (of stone, brick or adobe parts) above evenly to below owing to the ability of wood to work in tension well. They also act as buffers that prevent cracks from proceeding upwards, which were caused by seismic shocks or soil settlements, at the same time providing insulation against rising damp, especially in the parts of the walls close to the ground. When the natural length of the lace is not enough, they are joined through butt or half-lapped joints or juxtaposed simply with diagonal cuts and nailed to make longer structural members (Figure 12bd). In addition to sawn-timber laces, partial use of trunks in their natural shapes are common in the region. Ranging from $5-15 \mathrm{~cm}$ cross sectional dimensions of hatıls are quite variable in square, rectangular, or round sections.

\subsubsection{Infill-frame (hımış) walls}

Construction techniques similar to hımıs, known as opus craticium in the Roman Period (Adam 2005) are almost universal and proved to be "antiseismic" in timber structures. These techniques are not only found in Anatolia and neighboring countries but in many other parts of the world known as colombage in France, fachwerk in Germany, pombalino gaiola in Portugal, casa baraccata in Italy, and taq or dhajjidewari in India, for example (Langenbach 2007; Oikonomou and Bougiatioti 2011; Kouris and Kappos 2012; Makarios and Demosthenous 2006).

Hımıs walls, which are formed of timber frames articulated with studs, horizontal dividers and bracings and infilled with slate, fired or adobe brick, or mortared-rubble are used as partition walls between rooms and the walls between rooms and sofas together with masonry walls in İmir's rural area (Figure 13a). Some exterior walls of upper floors may also be of hımış (Figure 13b-d).

Rarely left exposed, the exterior and interior faces of these walls are usually covered with plaster, which is directly applied on the infilled frame or with the technique called bağdadi. In the bağdadi technique, plaster is applied on approximately $1-1.5 \mathrm{~cm}$ thick $2-2.5 \mathrm{~cm}$ wide horizontal strips of wood or reeds nailed on the members of timber frame with the same spans (Figure 14a-c). If the width of the wood strips extends $5 \mathrm{~cm}$, and 


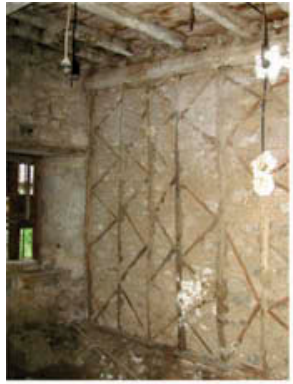

(a)

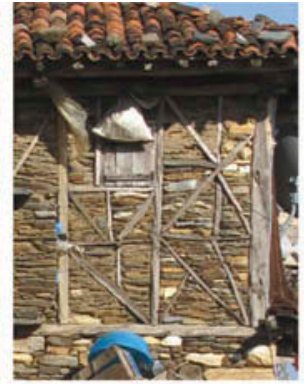

(b)

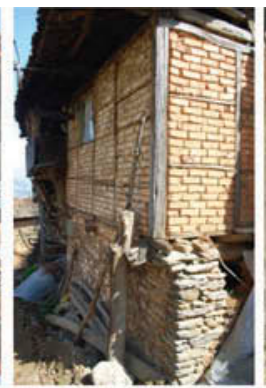

(c)

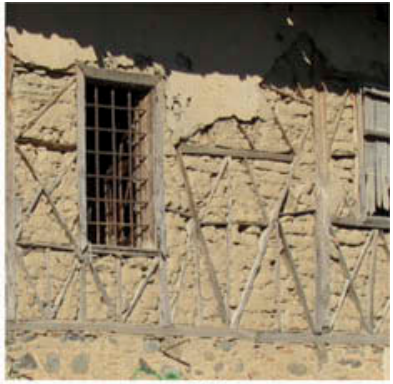

(d)

FIG. 13. Infill types of hımış frames: (a) interior wall (Bergama-Ferizler), (b) kayrak infill (Ödemiş-Suçıktı), (c) fired brick infill (Beydağ-Adaküre), and (d) adobe infill (Ödemiş-Mescitli).

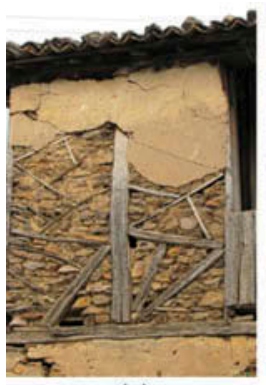

(a)

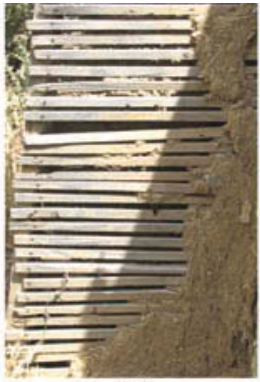

(b)

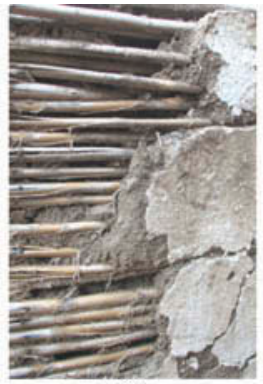

(c)

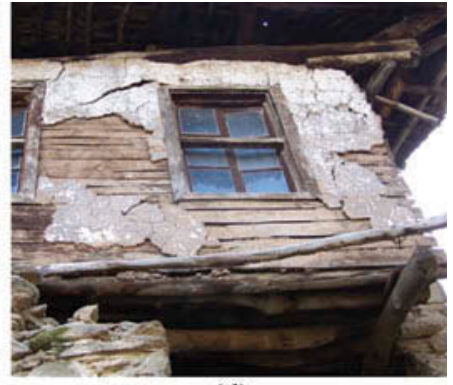

(d)

FIG. 14. (a) Mud plaster applied on hımış system (Kiraz-Yenişehir); bağdadi technique on: (b) wood strips (Karaburun-Küçükbahçe); (c) reeds (Urla-Zeytineli); (d) wider wood strips (Adaküre-Alakeçili).

are fixed by more nails, they may reinforce the structural stability of the overall frame. In such a case bağdadi technique can be regarded as a construction technique with a structural purpose (Gülkan and Langenbach 2004). Different from the aforementioned technique applied in waterside residences, the exterior faces of which were not plastered, the wooden bands seen on the facades of some houses in this region are notched to hold the plaster layer applied on their faces (Figure 14d).

Mud mortar is the most commonly used binder both in masonry and/or in infill-frame walls. This mortar is mainly composed of clay and a small amount of sand, and rarely with small amounts of lime and chopped straw. Except for the newly constructed or newly repaired houses where cement plaster is used, adobe (or mud) plaster is the most prominent rendering material used for traditional houses. It is composed of clay, chopped straw (which might be replaced with goat hair, fibers of linen, or cannabis as fibrous material), a small amount of lime, and animal dung, according to the villagers. The surfaces are lime-washed.

\subsubsection{Fireplaces and chimneys}

They are constructed simultaneously with the exterior masonry walls on the narrow sides of rooms and sofas. They can simply be included within the thickness of walls or with an additional protrusion of $15-20 \mathrm{~cm}$ both towards the interior and exterior. Fireplaces, $75-90 \mathrm{~cm}$ wide, $30-50 \mathrm{~cm}$ deep and mostly framed with segmented arches which can be plain or ornamented with floral figures and with protruding alcoves and shelves for candles and other goods for daily use (Figure 15ab). Fireplaces are used for cooking and heating. The exterior protrusions of fireplaces are raised on stone or wooden supports and tapered off at the width of chimneys below the eaves. Usually built of the same material and bonding type of fireplaces and the exterior walls of houses, the chimneys extend over the roof ridge with varying shapes and types of pots on top. Such arrangements give the rural houses of the region their typical appearance to (Figure 15c).

The flues of chimneys are usually constructed of fired brick. Some chimneys bonded with stone were said to be damaged in time due to the extreme heat. For this reason, many stone chimneys were replaced with fired brick, which is deemed relatively porous and heat-resistant (Figure 15d). In time the extensions of some chimneys over the roofs were also replaced with new bricks or metal pipes because of the damage caused by excessive heat and strong winds. The dimensions of fume holes are around $15-25 \mathrm{~cm}$.

\subsubsection{Frames of openings}

In addition to the materials and forms of the doors and windows in the openings, spanning elements like lintels and/or arches made of timber, stone or brick, influence the facade characteristics of rural houses. Lintels that are made of single blocks of andesite or limestone, with proper dimensions and homogeneity are used in the houses at some villages close 


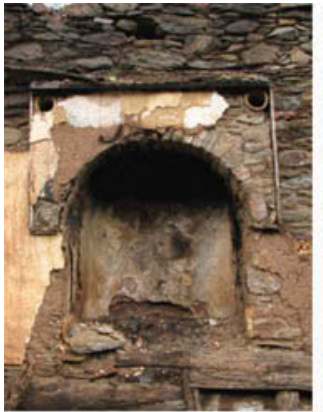

(a)

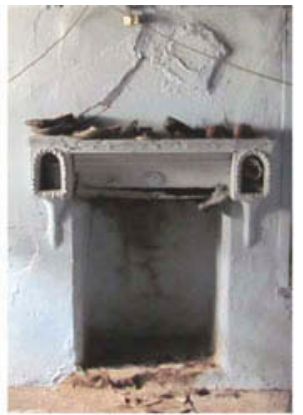

(b)

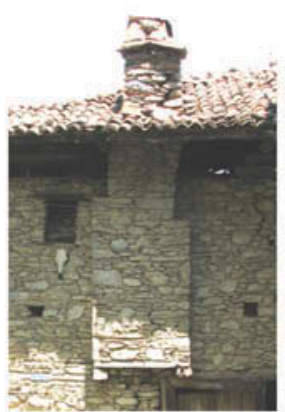

(c)

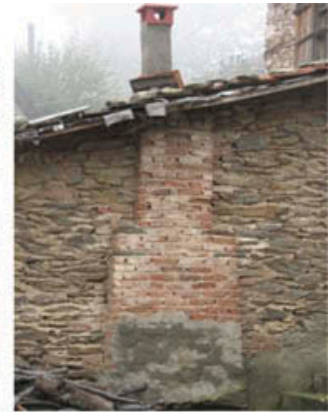

(d)

FIG. 15. A fireplace mantel with: (a) stone arch (Beydağ-Alakeçili), (b) ornamentation (Bergama-Ferizler), (c) typical exterior view (Beydağ-Çomaklı), and (d) brick replacement (Ödemiş-Kemer).

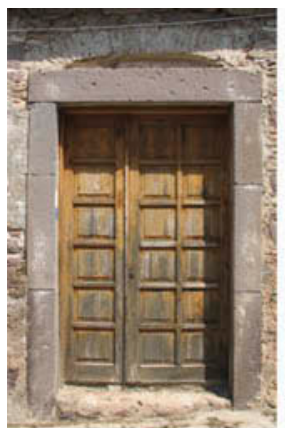

(a)

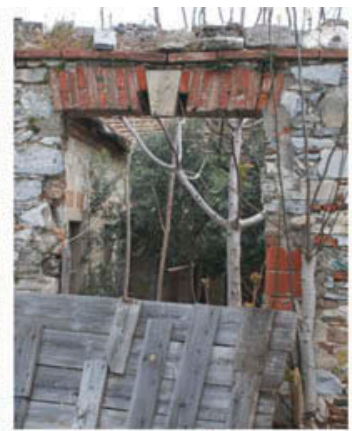

(b)

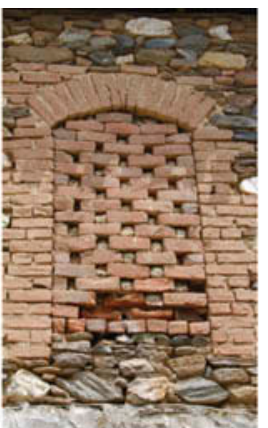

(c)

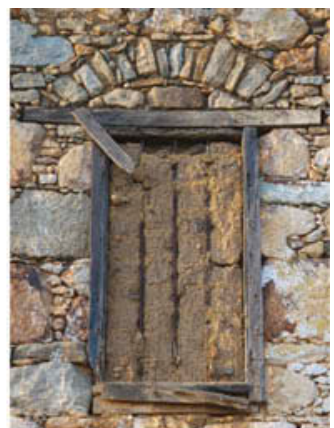

(d)

FIG. 16. Lintels: (a) andesite stone (Çeşme-Ildırı), (b) brick flat arch (Selçuk-Çamlık), (c) brick arch (Tire-Peşrefli), and (d) wood below relieving arch (BergamaSağanc1).

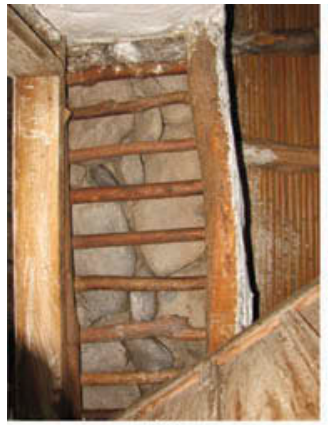

(a)

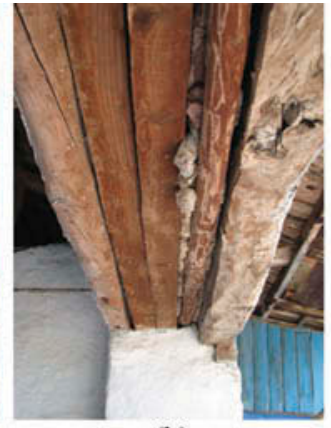

(b)

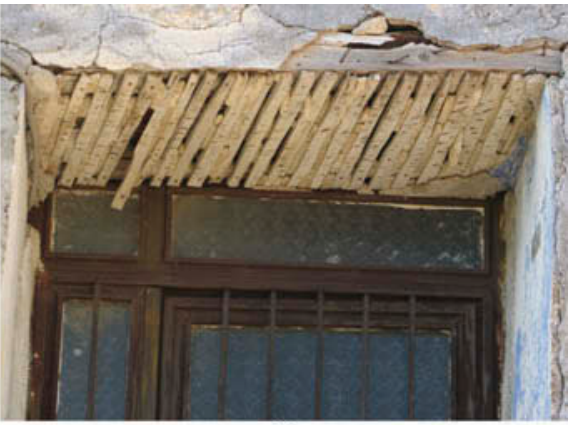

(c)

FIG. 17. (a) A ladder-like wood lintel (Bergama-Hisarköy); (b) multiple lintels (Kınık-Kocaömer); (c) wood lintel concealed with bağdadi strips (KaraburunKüçükbahçe).

to towns of commercial importance (Figure 16a). As well as stone, brick lintels in the form of flat arches, and brick or stone segmented arches were used for door and window openings (Figure 16b-d).

When compared with those made of stone or brick, timber lintels generally preferred as spanning elements for openings are. They are composed of trunks of $8-10 \mathrm{~cm}$ in diameter and placed at both faces of the wall. Transverse struts are nailed on them forming a ladder-like grid, or timber elements of the same shape and size are aligned side-by-side adjusting to the thickness of the wall (Figure 17a-b). The lintels of doors of the main entrance and rooms, and lintels of window openings of living spaces are either concealed with planks or plastered with bağdadi technique (Figure 17c). The frames of doors and windows are fixed to the jambs nailed to the battens set at both edges of the opening at the top, middle and close to the bottom.

\subsection{Floors}

\subsubsection{Floor systems}

Ground floors are of compacted earth and sometimes covered with kayrak slabs. Due to the evolving hygienic necessities in time, especially the floors of wet spaces were covered with 


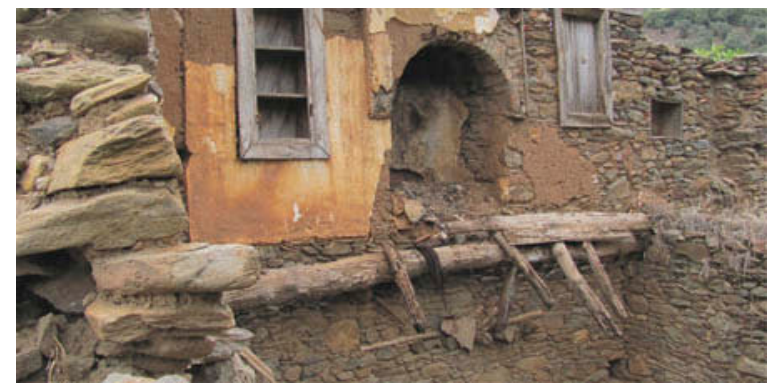

FIG. 18. Floor system of a collapsed house (Beydağ-Alakeçili).

screed. The system of upper floors is composed of girders resting on walls directly or through timber wall plates, and joists with nailed planks that are $2 \mathrm{~cm}$ thick and $20-25 \mathrm{~cm}$ wide (Figure 18).

The diameter of girders located on walls and at the center of the spaces varies from $15-17$ to $20-25 \mathrm{~cm}$ and of joists, placed with the intervals of $40-60 \mathrm{~cm}$, from $10-15 \mathrm{~cm}$. Similar to the timber laces mentioned previously, for beams and joists wood is used in its natural form. Such a use sometimes extends to the ramified parts of trunks that are utilized as headers of posts to hold the beams or the exterior-ends of beams to hold timber members that rest on them (Figure 19a-c).

\subsubsection{Projections}

4.2.2.1. Semi-open projections. Growing out of the first floor-beam system as semi-open extensions of the sofa, are subunits such as a washbasin, which also serves for ablution, a small kitchenette unit with a sink, and shelves for utensils that are projected above the upper level of the sofa-parapet wall. These timber-framed projections, $50-80 \mathrm{~cm}$ in depth, are supported by brackets connected to the wall plates of the first floor-beam system. The eaves above the sofa extend over these units. Such units of the first floor may also take place in a separate part supported with stone (in latter examples, briquette) masonry walls built apart from the house and connected to the sofa by means of a bridge-like semi-open corridor (Figure 20a). In such cases they may also include a lavatory and a toilet at their farthest edge enclosed with planks (Figure 20b).

The use of timber in its natural form is also available for the elements supporting these units. In contrast with the rest of the house some parts of the front side of the sofa and additional units visible from outside are latticed. In these parts, round section of timber elements becomes square and single, or double-piece capitals of posts are specifically carved. In addition to such exposed wooden elements at post and beam connections (Figure 21a-b), the rectangular spans between the posts of the sofas may take the shapes of arched openings with the use of bağdadi plastering technique (Figure 21c-d).

4.2.2.2. Bay windows. Although rarely projections enclosed with wood or hımış walls in which windows are placed are also observed at İzmir rural houses. These projections, the depths of which do not exceed $80 \mathrm{~cm}$-called jumbas - are carried by the extension of the sofa floor beams and supported with wood bracings set on the wall plates or laces. Brackets, composed of wrought or cast iron, are clinched

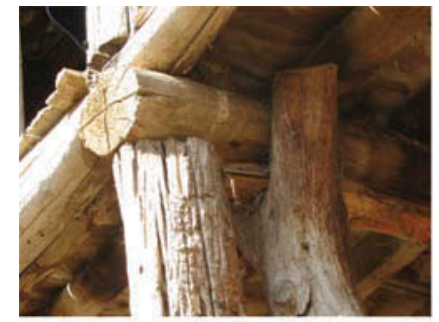

(a)

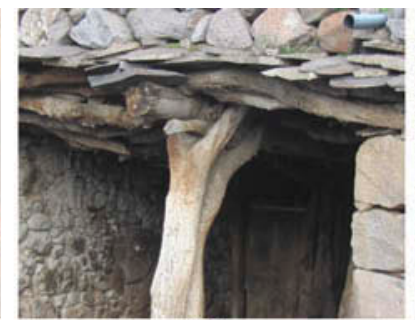

(b)

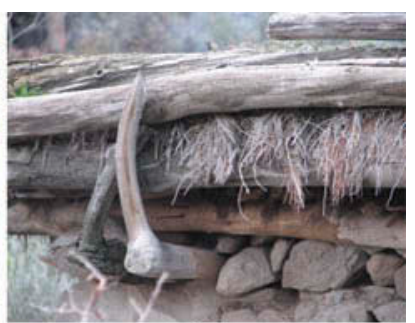

(c)

FIG. 19. Use of timber with natural forms: (a) sofa frame support (Kiraz-Karaburç), (b) support for flat roof beams (Aliağa-Kapıkaya), and (c) flat roof beams (Bergama-Yerlitahtac1).

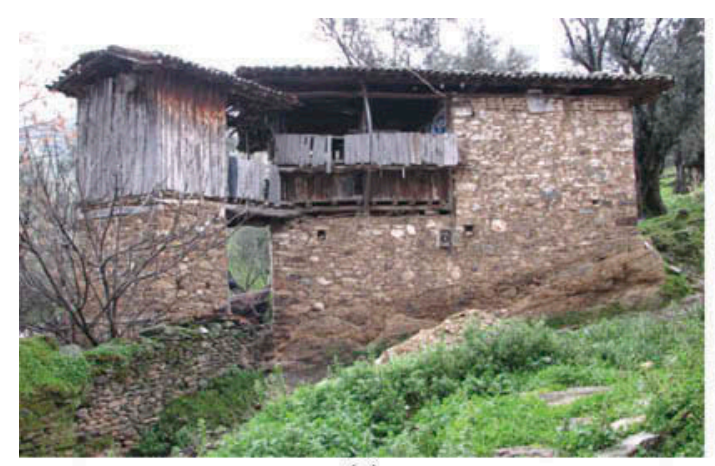

(a)

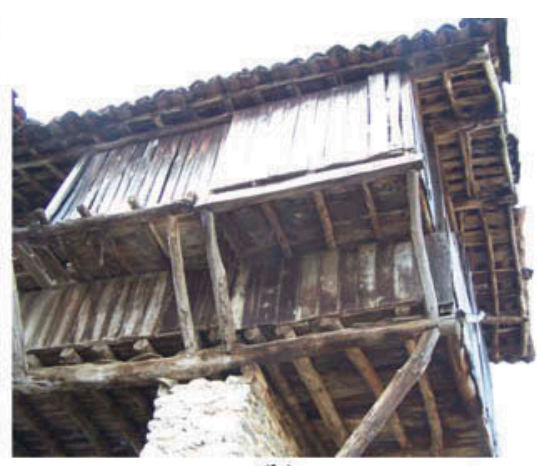

(b)

FIG. 20. Sofa extensions (Beydağ-Alakeçili): (a) plain, and (b) elaborate. 


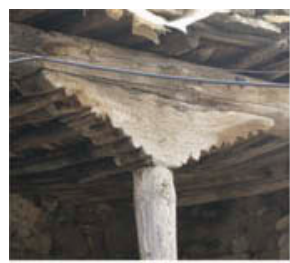

(a)

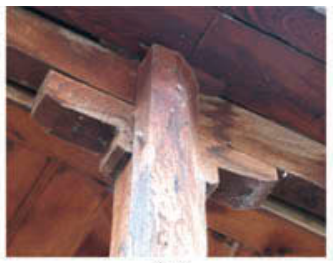

(b)

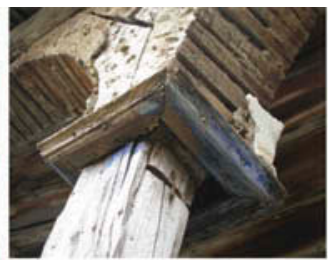

(c)

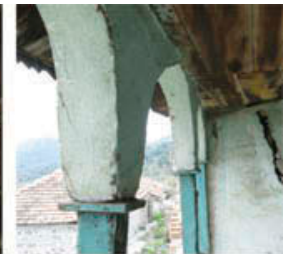

(d)

FIG. 21. Timber elements supporting roof-eaves of the sofas (Bergama-Yukarıkırıklar): (a) single-piece capital, (b) a double-piece capital, and (c-d) arch imitations with bağdadi technique.

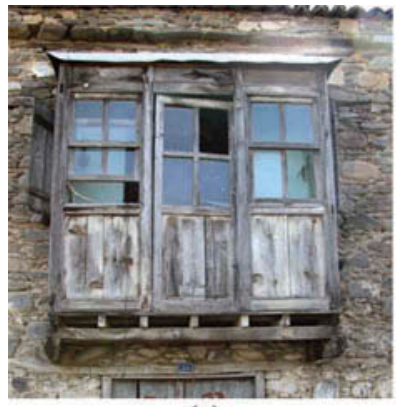

(a)

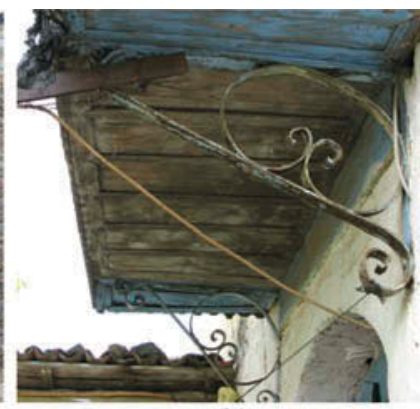

(b)

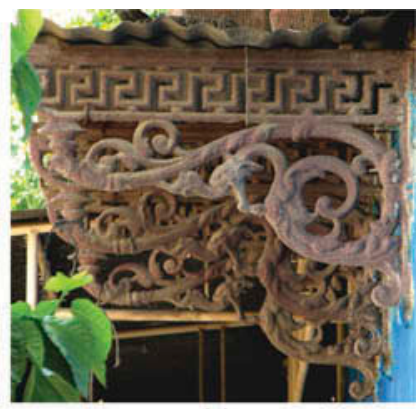

(c)

FIG. 22. Bay windows supported by: (a) first floor beams (Tire-Kırtepe), (b) wrought iron brackets, and (c) cast iron brackets (Tire-Kizılcahavlu).

to horizontal wrought iron strips that are hooked and nailed on the wall plates or the members of the first floor-frame system. The windows, which enclose these projections at three sides, contain vertical sliding sashes called giyotin (transliterated from guillotine in French) (Figure 22).

\subsubsection{Stairs}

The stairs examined in rural houses can be classified as those connecting the garden level to the ground floor, and the stairs connecting the ground floor to the sofas of upper floor(s). The first group is composed of rubble or rough-cut stone risers on a rubble stone base with treads of slate (kayrak) plates (Figure 23a).

Access to the first floors is usually provided by straight-run timber stairs connecting ground floors to the sofas of the first floors. In some houses, the opening of staircases at the sofas is closed with a door-like horizontal wooden shutter for safety and protection against dirt coming from the ground floors where stables, haylofts and storage spaces are located (Figure 23b). Supported by a three to four stepped-stone base on the ground and a sofa girder of the first floor, these stairs are constructed of two stringers, on which treads are fixed through the channels with almost equal width, or fixed on battens nailed to the stringers. A single stud resting on the stringer below and nailed to a sofa girder above, and a horizontal wooden bar fixed to the stringer and to the stud forms the balustrade employed in these simple stairs (Figure 23c). In addition to the simple stairs with door-like horizontal shutters at the sofa floor, other stairs without shutters but with well-shaped wooden balusters and handrails that enclose the staircase-opening at the sofa floor are observed (Figure 23d).

\subsubsection{Roofs and Eaves}

Hipped roofs, covered with round Turkish tiles (called alaturka-transliterated from the word a la turca in French) form the major group of roof construction in rural houses. Although usually preferred for separately built animal barns, houses with flat roofs covered with rammed earth or kayrak slabs are also observed.

In addition to roof constructions resting on wall purlins and girders, trusses with hanging posts are normally preferred for larger spans were also employed for narrow spans in many houses (Figure 24a). Tiles are placed either directly on the battens or planks, or on reed mats nailed on rafters.

Similar matting materials are applied for covering the ceilings of the rooms under the roof. In the room ceilings of some houses, the reeds or lathes nailed on the roof girders and trusses are plastered in the bağdadi technique (Figure 24b). However, majority of the ceiling covering materials under the roof floor are planks, which are $1-1.5 \mathrm{~cm}$ thick and $20-25 \mathrm{~cm}$ wide nailed to the soffits of joists. Usually, the joints between planks are concealed with wood slats forming a grid pattern on the ceiling (Figure 24c). In addition to plain ceilings, richly decorated ones constructed in the same way are also seen in the houses of the wealthy villagers (Figure 24d). Different from room ceilings, ceilings of the most sofas are exposed and roof constructions are visible facilitating ventilation of the roofs. The ceilings of the ground floor spaces that are used as service units have no cover.

Although usually preferred for animal barns, stone or adobe brick masonry houses with flat roofs are also seen. They are composed of timber beams set on wall plates and joists on 


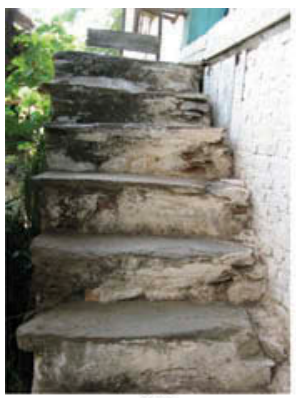

(a)

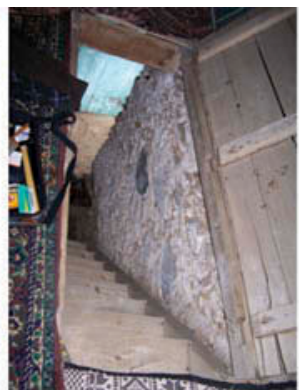

(b)

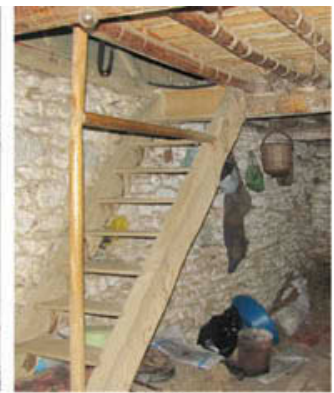

(c)

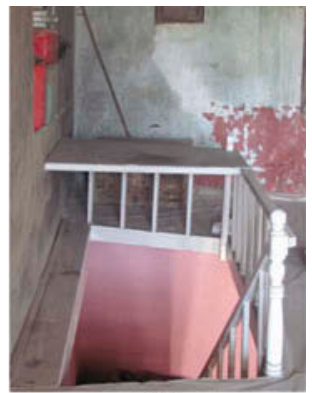

(d)

FIG. 23. Stairs with: (a) kayrak (Tire-Kızılcahavlu), (b) door-like shutter (Beydağ-Alakeçili), (c) simple baluster (Beydağ-Alakeçili), and (d) ornamented baluster (Tire-Kızılcahavlu).

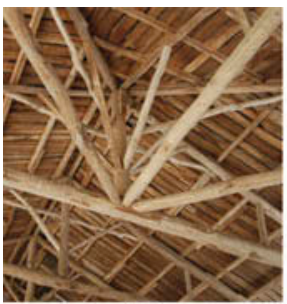

(a)

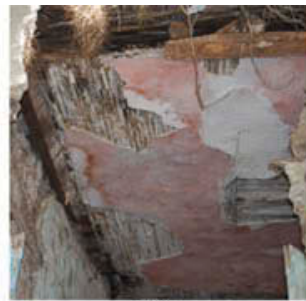

(b)

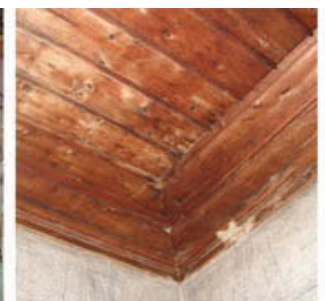

(c)

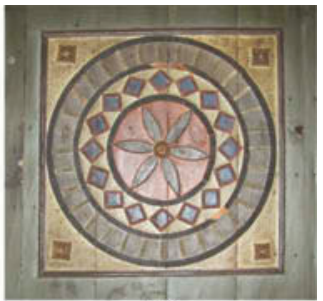

(d)

FIG. 24. (a) Roof truss with hanging post (Tire-Kızılcahavlu) and ceilings with: (b) reed matting with plaster (Bergama-Sarıcalar), (c) planks (Çeşme-Ildırı), and (d) ornaments (Bergama-Sarıcalar).

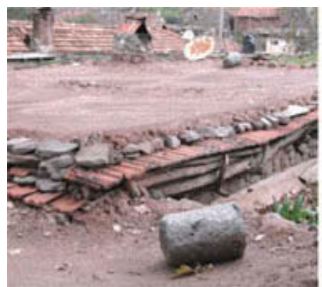

(a)

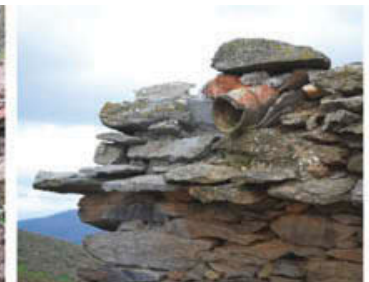

(b)

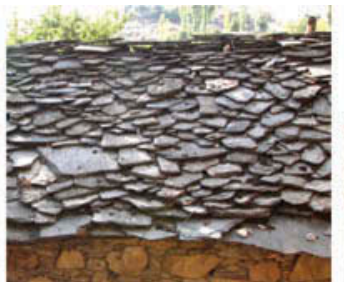

(c)

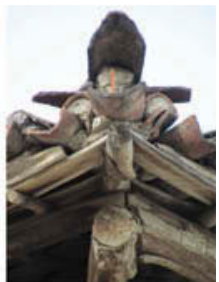

(d)

FIG. 25. Roofs with: (a) rammed earth (Bergama-Yerlitahtacı), (b) eaves with drainage pipe (Karaburun-Sarpıncik), (c) kayrak (Kiraz-Cevizli), and (d) figures with round tiles (Tire-Peşrefli).

which planks or reed mats are nailed. Flat roofs are covered with rammed earth with high clay content. After rainfall the earth layer is squeezed with a stone-roller called $\log$ (or lov or $y u \breve{g}$ ) in order to drain the water accumulated and to prevent pooling on the roof as maintenance precaution. Rain or squeezed water is directly drained from eaves or through terracotta pipes embedded in the eaves (Figure 25a-b). Flat roofs covered with kayrak slabs laid out on an earth layer that is supported by timber roof structures are also observed in some villages (Figure 25c). Most of the timber elements of these roofs are also used in their natural forms.

Eaves, being important components of roofs can be classified as those composed of wood, kayrak plates and rows of bricks in variable patterns, depending on the local conditions of material supply. While identical eaves can be observed in one village, it is possible to see the same type in neighboring villages. Wooden eaves, as a frequently seen eave type project
$20-60 \mathrm{~cm}$ from wall surfaces. The width of eaves reaches $1-1.5 \mathrm{~m}$. above the sofas. They can be mere outward extensions of roof constructions without veneer or can be covered with plain or ornamented boards on their fascia and soffits. Stylistic arrangements of round tiles obtained by different arrangements are also seen at the end of hip purlins of the roofs (Figure 25d). In the roofs, which extend outward from wall surfaces, the spans between rafters, which vary from $40-60 \mathrm{~cm}$ are usually left empty to provide ventilation in the roof space due to climatic factors.

The eaves composed of a single or double rows of kayrak form the second group. They are preferred not only for hipped roofs but also for houses with flat roofs (Figure 25b).

Brick eaves formed by the alignment of brick units with plain or diagonal projections that run around the roof make up a third group in houses built of brick (Figure 9c) and, sometimes, of stone. Except for those that were attached later, gutters and 
downspouts are never observed at the roofs of authentic rural houses of İzmir.

\section{DOOR AND WINDOW ASSEMBLAGES}

\subsection{Doors}

Doors of houses are evaluated as the entrance doors of the house, stables, storage spaces for hay and/or other utensils, and the doors that provide access to the rooms from the sofas.

\subsubsection{Entrance doors to the house}

The houses accessed directly from streets, gardens or courtyards possess plain matchboard doors with single or doublewings with wood, kayrak, or marble thresholds. More elaborate entrance doors of wood or metal, possess double wings with panels and top windows assembled in the openings, of $175 \mathrm{~cm}$ width and $330 \mathrm{~cm}$ height, are also seen.

The main floors of most of the double-story houses are accessed from the gardens or courtyards via the staircases leading to the sofa. However, at single-story houses where the main floor is the ground floor these spaces are accessed from garden or courtyard through the sofa, which is elevated from the ground and reached by stairs with two to three steps. Wooden doors are framed with wooden, and rarely, stone casings. They have wooden thresholds.

\subsubsection{Doors of stables and other service units}

The doors of these units are of simple batten doors that consist of vertical planks with variable widths of $(10-20 \mathrm{~cm})$ and thickness of $(2-2.5 \mathrm{~cm})$, nailed on ledgers and sometimes on diagonal braces. The width of doors with single wings varies between 80 and $120 \mathrm{~cm}$, and of the doors with double wings vary between 120 and $180 \mathrm{~cm}$. Their heights do not exceed $200 \mathrm{~cm}$.

\subsubsection{Doors of entrance to the rooms}

The rooms accessed through the sofas usually possess simple single-winged matchboard doors, $70-80 \mathrm{~cm}$ wide and $190-200 \mathrm{~cm}$ high, with wood casings $10-15 \mathrm{~cm}$ wide. They may also be double-winged (usually on the axis of the wall), paneled or ornamented with slats.

\subsection{Windows}

Similar to doors, windows are evaluated as those opened to the public, gardens or courtyards, and to the sofas. Except for the shutters made of wood or metal sheets attached to the windows opening to public spaces, private gardens and courtyards, there is no specific difference between their casings (stone or wood) and sashes. All types may have single or double-wings, or vertical sliding sashes. In addition to the shutters made of wood, windows especially opening to public spaces may also possess plain or ornamented wood or iron grids for safety. On the contrary to those found in cold climates, which possess double sashes, windows in this region possess single sashes. Most windows are framed with wooden casings. With the approximate ratio of $1: 2$, the dimensions of windows of İzmir rural houses varied between $60-80 \mathrm{~cm}$ in width and $120-150 \mathrm{~cm}$ in height.

\section{PROBLEMS}

\subsection{Alterations}

Apart from the replacement of original round roof tiles with industrially produced western types or with corrugated metal or asbestos cement sheets, the most prominent alterations occurred due to division of the houses by inheritors, the addition of new spaces, and the conversions of existing spaces in order to provide wet spaces such as kitchens, toilets, and bathrooms. While causing architectural degeneration, the use of reinforced concrete in alterations (e.g., slabs without engineering consultancy) overburden the buildings, the original structure of which is not strong enough. In addition, the use of hollow bricks-the real purpose of which is not structural, and its use should be limited to partition walls-on these slabs as "load bearing masonry walls" without any support is another risk for the houses (Figure 26a-b). The application of cementitious materials (as screed for floor covering, cement mortars for fixing ceramic tile covers on floor and wall surfaces) containing high amount of water-soluble salts harmful for the original porous-material fabric of the houses are the other present and future threats regarding material decays and structural problems.

Another potential structural threat is the enlargement of original doors and windows to get more light and air without respect for the original not only in hımış walls but also in the masonry structure (Figure 26c). Such random changes decrease the load bearing-capacity of the masonry structure and the removal of diagonal braces previously placed in hımış walls cause the decrease in seismic stability of the frames (Tobriner 2000; Doğangün, Tuluk Livaoğlu, and Acar 2006). In addition to structural damage, such enlargements result in the loss of original facade proportions and architectural degeneration.

When compared to hımış walls constructed without braces (Figure 13c and 26c), the majority of himıs walls in the region possessed braces in their frames.

\subsection{Structural Failures}

Due to the lack of permanent maintenance and/or the abandonment of the houses, the main reason that triggers structural failures is the rainwater penetration from the damaged parts of the roofs. In such cases, water leakage from a damaged roof into the core of the walls dissolves mud mortar and weakens the integrity between masonry units. The lack of periodical repairs of the roofs, weakened mud-mortared joints, and losses of exterior plaster with lime wash (which is particularly important for adobe brick structures and exterior faces of plastered hımıs 


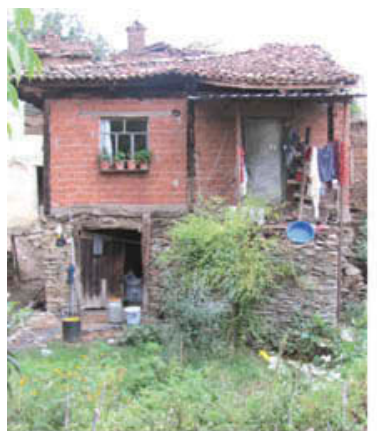

(a)

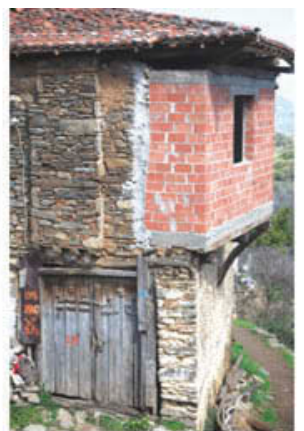

(b)

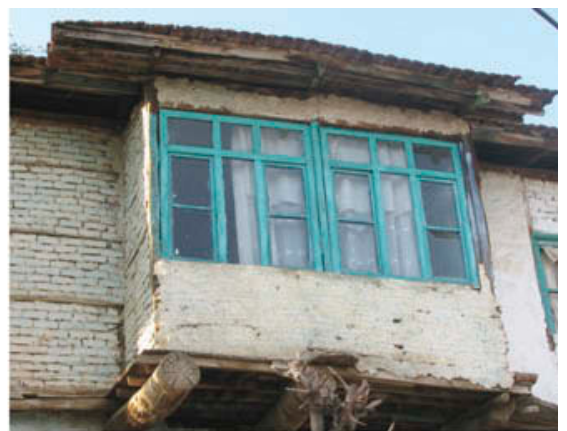

(c)

FIG. 26. Spatial changes with: (a-b) RC slab and hollow bricks walls (Beydağ-Alakeçili), and (c) window enlargement of a bay window in hımış frame with brick infill (Kiraz-Karaburç).

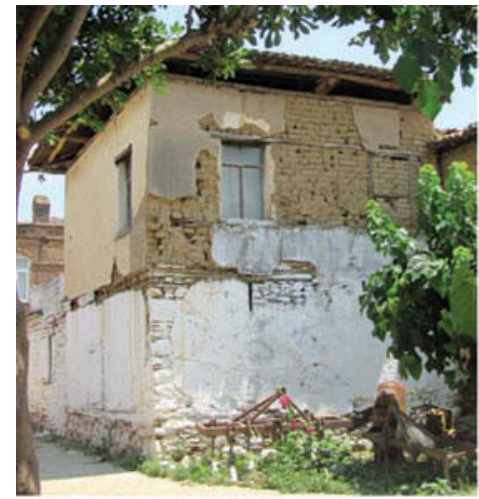

(a)

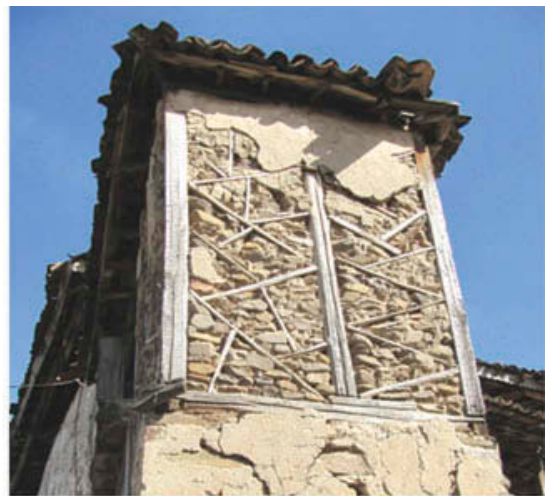

(b)

FIG. 27. Plaster losses on the surfaces of: (a) an adobe brick-masonry house (Tire-Kızılcahavlu), and (b) a hımış exterior wall on stone masonry (Tire-Yenişehir).

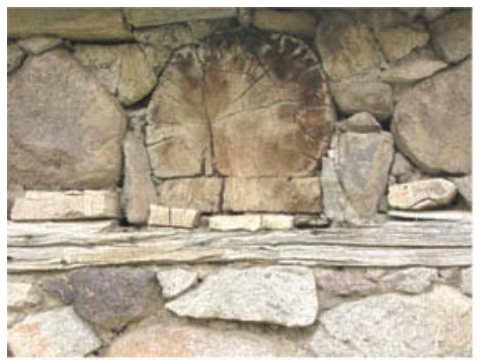

(a)

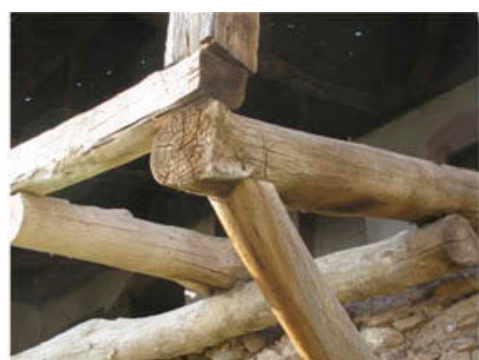

(b)

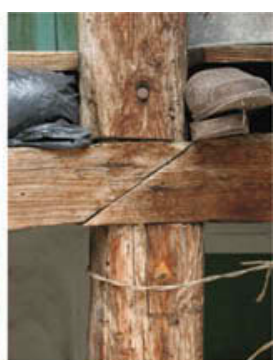

(c)

FIG. 28. (a) A proper placement of a round timber beam (Bergama-Yukarıkırıklar), faulty assemblages in post and beam connections at sofas: (b) Kiraz-Karaburç, and (c) Kınık-Kocaömer.

walls) are other important reasons for damages (Figure 27a-b). Water penetration also causes insect infestation, which is one of the major causes of decay in the timber components of the houses. The embedding beams into masonry walls and timber post-beam connections vary. Apart from beams placed in the walls without wall-plates, careful assemblages where the placement of round beams through flat-topped ends on wall plates or hatıls, buffered by lateral laths or stone pieces with mortar that prevent them from rolling off are observed (Figure 28a). However post and beam connections done by slightly concaved ends of round posts and brackets which hold the round beams, and beam joints obtained by mere diagonal cuts without lateral restrictions are prone to sliding and are considered as structurally weak characteristics (Tobriner 2000; Hughes 2000a; 2000b) (Figure 28b-c).

The sagging observed at the beams of flooring systems that might have occurred gradually and that has not reached the degree of structural failure are considered progressing deformations, which might cause the beams to slip out of supporting wall-plates or the walls without wall-plates. 


\section{EVALUATION AND CONCLUSION}

Despite variable geographical conditions, spatial layouts of original Izzmir rural houses remain constant even in the remotest parts of the region. Together with these constant plan layouts, the facade compositions, roofs, fireplace and chimney arrangements, window and door openings, and wall textures constitute a built-environment peculiar to the region. Differences mostly arise from varying raw material sources available around the settlements.

Their regular plan geometries, which are usually rectangular, low height-to-base ratios, as they are maximum double-story buildings, and equal floor heights that do not exceed $2.6 \mathrm{~m}$ reveal that a regular structural configuration was achieved as far as an overall seismic stability is concerned (Tobriner 2000). Despite some defective details in timber components and the use of soft mud mortar in the masonry walls, many dwellings built with these techniques are still in use and in good condition. The use of hatıls in the masonry and relatively light hımıs walls might have played important roles in their resistance against earthquakes endemic to the entire region.

Providing a large frictional surface, horizontally laid kayrak slabs likely contributed to the seismic stability of walls despite the use of mortar with low mechanical strength when compared to the mortars prepared with lime, hydraulic lime, or cement. However, the use of such a weak mortar might have been an advantage, most likely due to the energy generated by seismic shocks is dissipated by the occurrence of small local crushes limited to the joint mortars, and hence, the occurrence of larger displacements in the fabric are prevented by the "additional contribution" of hatıls. Although this study is not specifically focused on the seismic stability of rural houses, the soundness of kayrak masonry walls that are laid with relatively weak mortar call for further studies reconsidering seismic performance of traditional masonry walls as partially discussed by Gülkan and Langenbach (2004).

In the same context, the adobe brick that formed a considerable portion of the architectural heritage and known as an "eco-friendly" but weak material for seismic resistance still seems a promising material with some improvements (Turanli and Saritas 2011). If sufficiently supported with timber members, and protected against water by plastering with adobe and lime wash, as it was in the past, adobe brick can also be safely used for the construction of small-scale buildings and the repair of damaged adobe buildings in these settlements.

Excluding architectural degenerations by spatial additions, inadequate interventions and destruction due to the abandonment and lack of maintenance, plenty of rural dwellings in İzmir villages are still sound and reflect geographical characteristics of their environments, construction techniques and sociocultural values of rural life in the past. The following are the suggestions for a holistic approach for the preservation and sustainability of this heritage:
- The use of hattl in masonry walls (even laid with weak mud mortar) and the hımıs walling system, which is the most prominent technique forming an important ring of the earthquake-proof building technology chain - employed not only around Izmir and the rest of Anatolia but in many other countries-can be sustained in the repair of the damaged houses.

- Including the collapsed houses, slightly or severely damaged houses should be considered as openlaboratories. They exhibit not only the merits of hatıl or hımıs techniques but may also offer other inspiring skillful solutions not easily perceived from intact houses. For this purpose, the workshops to be organized in the selected pilot villages and organized under the guidance of academics, restorers, conservators, professional architects, and engineers involved in traditional building technology are suggested. While offering in situ education to the young craftsmen, this approach can be a good start for not only revitalizing rural houses but may also invigorate the disappeared guilds in rural areas that existed in the past. Such an approach will not only help preserve this cultural heritage, but will also be helpful in regaining an extensive housing stock abandoned in built environments that remain untouched by urbanization and industrialization.

- At present, all villages possess water supply networks that are carried out by the Special Provincial Administration of İzmir Governorship and other public bodies. Therefore every house has the possibility to take water into the house. This possibility may give way to provide installations for wet spaces such as toilets, bathing units, and kitchens. Such minimum contemporary conditions, especially desired by housewives and elders of the families, can be realized with the aforementioned "professional-technical" assistance by the consideration of architectural and structural features of the houses in order to prevent further degeneration.

- Rural life should be encouraged through decisive political strategies and development plans to be based on the realities of Izmir villages for the improvement of existing living conditions.

\section{ACKNOWLEDGEMENT}

The authors wish to thank Leyla Gürsel (BArch), Deniz Coşkun (PhD), Aslı Özaylak (MCP) and Samet Kayhan (BCE) of the Special Provincial Administration of İzmir Governorship for their invaluable assistance throughout this period. Thanks are extended to Professor Dr. Murat Günaydın, coordinator of the work and the Dean of Faculty of Architecture of İzmir 
Institute of Technology and to IZTEK A.Ş. Special thanks are due to Associate Professor Dr. Erdem Erten for his careful editing and invaluable remarks.

\section{FUNDING}

The field research and the following inventory effort were funded by the Special Provincial Administration of İzmir Governorship.

\section{REFERENCES}

Adam, J. P. 2005. Roman building_Materials and techniques. London, UK Routledge-Taylor \& Francis Group.

Adorni, E., E. Coïsson, and D. Ferretti. 2013. In situ characterization of archaeological adobe bricks. Construction and Building Materials 40: $1-9$.

Aksoy, E. 1962. Orta Mekân: Türk Sivil Mimarisinde Temel Kuruluş Prensibi [in Turkish]. Mimarlık ve Sanat 7-8:39-92.

Asatekin, G. 2005. Understanding traditional residential architecture in Anatolia. Journal of Architecture 10(4):389-414.

Baine, D., B. Puhan, G. Puhan, and S. Puhan. 2000. An ecological inventory approach to developing curricula for rural areas of developing countries International Review of Education 46(1-2):49-66.

Batur, A. 2005. Doğи Karadeniz'de Kırsal Mimari [Rural architecture in the Eastern Black Sea Region]. Istanbul, Turkey: Milli Reasürans TAŞ and Mas Matbaacılık AŞ.

Cardinale, N., G. Rospi, and P. Stefanizzi. 2013. Energy and microclimatic performance of Mediterranean vernacular buildings: The Sassi District of Matera and the Trulli District of Alberobello. Building and Environment 59: 590-598.

Chen, T. 2012. Case study: The rescue, conservation and restoration of heritage sites in the ethnic minority areas ravaged by the Wenchuan earthquake. Frontiers Architectural Research 1: 77-85.

Çorapçıŏlu, K., Çakır, S., Aysel, N. R., Görgülü, H. C, Kolbay, D., Seçkin, N. P. and Ünsal, E. 2008. Kayseri Kırsalında Yöresel Mimari Özelliklerin Belirlenmesi[in Turkish]. İstanbul, Turkey: Mimar Sinan Güzel Sanatlar Üniversitesi Döner Sermaye İşletmesi Müdürlüğü.

Çorapçıŏlu, K., Diri, C., Diri, B. Ş., Kurugöl, S., Özgünler, M., Erem, Ö., Gökuç, Y. T., Görgülü, H. C., Seçkin, P. and Oğuz, Z. 2011. Ballkesir Kırsalında Yöresel Doku ve Mimari Özelliklere Uygun Yapılaşmanın Yaygınlaştırılması [in Turkish]. Ankara, Turkey: Bayındırlık ve İskan Bakanlığı Teknik Araştırma Uygulama Genel Müdürlüğü.

Delgado, M. C. J., and I. C. Guerrero. 2006. Earth building in Spain. Construction and Building Materials 20(9):679-690.

Dickinson, R. E. 1949. Rural settlements in the German lands. Annals of the Association of American Geographers 39(4):239-263.

Doğangün, A., Ö. İ., R. Tuluk Livaoğlu, and R. Acar. 2006. Traditional wooden buildings and their damages during earthquakes in Turkey. Engineering Failure Analysis 13(6):981-996.

Eldem, S. H. 1955. Türk Evi Plan Tipleri [in Turkish]. Istanbul, Turkey: Istanbul Technical University.

Enayat, A. 1952. Rural settlement types in the Uttar Pradesh [United Provinces of Agra and Oudh]. Annals of the Association of American Geographers 42(3):223-246.

Eriç, M. 1979. Gelenksel Türk Mimarisinde Malzeme Seçim ve Kullanımı [in Turkish]. Yapı 33: 42-45.

Erpi, F. 1975. İzmir'de Levanten Mimarisi [in Turkish]. Mimarlık 1: 15-18.

Erpi, F. 1987. Buca'da Konut Mimarisi (1838-1934) [in Turkish]. Ankara, Turkey: Middle East Technical University (O.D.T.Ü.).

Fuentes, J. M. 2010. Methodological bases for documenting and reusing vernacular farm architecture. Journal of Cultural Heritage 11: 119-129.

Goodhew, S., and R. Griffiths. 2005. Sustainable earth walls to meet the building regulations. Energy and Buildings 37: 451-459.

Gülkan, P., and R. Langenbach. 2004. The earthquake resistance of traditional timber and masonry dwellings in Turkey. In Proceedings of the 13th
World Conference on Earthquake Engineering, Vancouver, BC, Canada, August 1-6, 2004. Paper no. 2297. Canadian Association for Earthquake Engineering and International Association for Earthquake Engineering.

Günay, R. 1998. Tradition of the Turkish house and Safranbolu houses. İstanbul, Turkey: Yapı Endüstri Merkezi Yayınları.

Hanan, H. 2012. Modernization and cultural transformation: The expansion of traditional Batak Toba House in Huta Siallagan. Procedia-Social and Behavioral Sciences 50: 800-811.

Hughes, R. 2000a. Cator and cribbage construction of Northern Pakistan. In Proceedings of Earthquake-Safe: Lessons To Be Learned From Traditional Construction- International Conference on the Seismic Performance of Traditional Buildings. Istanbul, Turkey, November 16-18, 2000. İstanbul, Turkey: ICOMOS. Retrieved from http://www.icomos.org/ iiwc/istanbul2000.htm

Hughes, R. 2000b. Hat1l construction in Turkey. In Proceedings of EarthquakeSafe: Lessons To Be Learned From Traditional ConstructionsInternational Conference on the Seismic Performance of Traditional Buildings. Istanbul, Turkey, November 16-18, 2000. İstanbul, Turkey: ICOMOS. Retrieved from http://www.icomos.org/iiwc/istanbul2000.htm

Irgat Ergin, B. 2008. The examination of construction techniques of Muğla historic houses. İzmir Institute of Technology Master's Thesis. Urla/Izmir, Turkey.

Kafesçioğlu, R. 1949. Orta Anadoluda Köy Evlerinin Yapısı [in Turkish]. Istanbul, Turkey: Istanbul Technical University.

Kafesçioğlu, R. 1955. Kuzey-Batı Anadolu'da Ahşap Ev Yapıları [in Turkish]. İstanbul, Turkey: Pulhan Matbaası.

Kazmaoğlu, M., and U. Tanyeli. 1979. Anadolu Konut Mimarisinde Bölgesel Farklılıklar [in Turkish]. Yapı 33: 29-41.

Köse, A. 2005. Türkiye'de Geleneksel Kırsal Konut Planlarında Göçebe Türk Kültürü İzleri [in Turkish]. Afyon Kocatepe Üniversitesi Sosyal Bilimler Dergisi VII(2): 165-200.

Kouris, L. A. S., and Kappos, A. J. 2012. Detailed and simplified non-linear models for timber-framed masonry structures. Journal of Cultural Heritage 13: 47-58.

Kuban, D. 1995. The Turkish Hayat house. İstanbul, Turkey: Eren Yayıncılık ve Kitapçılık Ltd. Şti.

Küçükerman, Ö. 2007. Kendi mekânının arayışı içinde Türk evi/Turkish house: In search of spatial identity [in Turkish and English]. Istanbul, Turkey: Türkiye Turing ve Otomobil Kurumu.

Langenbach, R. 2007. From "opus craticium" to the "Chicago frame": Earthquake resistant traditional construction. International Journal of Architectural Heritage 1: 29-59.

Makarios, T., and Demosthenous, M. 2006. Seismic response of traditional buildings of Lefkas Island, Greece. Engineering Structures 28: 264-278.

Maden Tetkik Ve Arama Genel Müdürlüğü (MTA) [Mineral Research \& Exploration General Directorate]. 2005. İzmir Yakın Çevresinin Diri Fayları ve Deprem Potansiyelleri [in Turkish]. Çankaya, Ankara Turkey: MTA, MTA Rapor No: 10754

Murakami, Y. 2000. Lessons in the strengthening and reinforcement of historical buildings from rescue projects following the Great Hanshin Earthquake. In Proceedings of Earthquake-Safe: Lessons To Be Learned From Traditional Construction-International Conference on the Seismic Performance of Traditional Buildings. Istanbul, Turkey, November 16-18, 2000. İstanbul, Turkey: ICOMOS. Retrieved from http://www.icomos.org/ iiwc/istanbul2000.htm

Ngowi, A. B. 1997. Improving the traditional earth construction: A case study of Bostwana. Construction and Building Materials 11(1):1-7.

Oikonomou, A., and F. Bougiatioti. 2011. Architectural structure and environmental performance of the traditional buildings in Florina, NW Greece. Building and Environment 46: 669-689.

Okay, A. İ. 2008. Geology of Turkey: A synopsis. Anschnitt 21: 21-42.

Özgüner, O. 1970. Köyde Mimari/Doğu Karadeniz [in Turkish]. Orta Doğu Teknik Üniversitesi Mimarlık Fakültesi. Ankara, Turkey: Middle East Technical University (O.D.T.Ü.).

Pachego-Torgal, F., and S. Jalali, S. 2012. Earth construction: Lessons from the past for future eco-efficient construction. Construction and Building Materials 29: 512-519. 
Quagliarini, E., and S. Lenci. 2010. The influence of natural stabilizers and natural fibers on the mechanical properties of ancient Roman adobe bricks. Journal of Cultural Heritage 11: 309-314.

Şahin Güçhan, N. 2007. Observations on earthquake resistance traditional timber-framed houses in Turkey. Building and Environment 42: 840-851.

Saleh, M. A. E. 2001. Environmental cognition in the vernacular landscape: Assessing the aesthetic quality of Al-Alkhalaf village, Southwestern Saudi Arabia. Building and Environment 36: 965-979.

Silveira, D., H. Varum, A. Costa, T. Martins, H. Pereira, and J. Almeida. 2012. Mechanical properties of adobe bricks in ancient constructions. Construction and Building Materials 28: 36-44.

Tobriner, S. 2000. Wooden architecture and earthquakes in Turkey: A reconnaissance report and commentary on the performance of wooden structures in the Turkish earthquakes of 17 August and 12 November 1999. In Proceedings of Earthquake-Safe: Lessons To Be Learned From Traditional Construction-International Conference on the Seismic Performance of Traditional Buildings. Istanbul, Turkey, November 16-18, 2000. İstanbul, Turkey: ICOMOS. Retrieved from http://www.icomos.org/ iiwc/istanbul2000.htm
Torreggiani, D., and P. Tassinari. 2012. Landscape quality of farm buildings: The evolution of the design approach in Italy. Journal of Cultural Heritage 13: 59-68.

Tunçoku, S. S., Avar, A., İnceköse, Ü., Akış, T. and Yalçın, M. A. 2012. Izmir Kırsal Alan Yerleşim ve Konut Envanteri [in Turkish, The Inventory of the Settlements and Houses of Izmir Rural and Provision of Exemplary House Projects]. Izmir, Turkey: Çınar Matbaacılık/Special Provincial Administration of İzmir Governorship.

Turanli, L., and A. Saritas. 2011. Strengthening the structural behavior of adobe walls through the use of plaster reinforcement mesh. Construction and Building Materials 25: $1747-1752$.

Vissilia, A. M. 2009. Evaluation of a sustainable Greek vernacular settlement and its landscape: Architectural typology and building physics. Building and Environment 44: 1095-1106.

Yetgin, Ş., Ö. Çavdar, and A. Çavdar. 2008. The effects of the fiber contents on the mechanic properties of the adobes. Construction and Building Materials 22: $222-227$. 